\title{
POLITIKK
}

\section{Diplomatisk hodebry: internasjonale reaksjoner på utvalgte avgjørelser i norsk barnevern}

\author{
Sunniva Cristina Bragdø-Ellenes \\ Universitet i Agder, Institutt for rettsvitenskap \\ Stina Torjesen ${ }^{\star}$ \\ Universitet $i$ Agder, Institutt for økonomi
}

\begin{abstract}
Sammendrag
De siste ti årene har enkelte avgjørelser i norsk barnevern skapt sterke internasjonale reaksjoner. Våren 2016 demonstrerte over 8000 personer i elleve land i forbindelse med en sak som angikk en norsk-rumensk familie. Denne artikkelen undersøker tre saker som har gitt Norge betydelige diplomatiske utfordringer (India 2011, Russland 2014 og Romania 2016). Artikkelen ser på hvorfor sakene utløste så sterke reaksjoner, og redegjør for hvordan norske myndigheter håndterte sakene. Vi beskriver også gjeldende norsk lovverk og prosedyrer på feltet. Et viktig funn i vår undersøkelse er at alle sakene kan knyttes til andre sterke drivkrefter i det aktuelle landet. Det er kombinasjonen av en dramatisk familiehistorie i møte med en større politisk agenda som gjør sakene så kraftfulle og betente i de enkelte landene. I materialet vi legger frem, finner vi også tegn til læring og forbedring i Utenriksdepartementets (UD) håndtering, og også utvikling og forbedring i måten UD har samarbeidet med andre deler av embetsverket på. Samtidig stiller artikkelen spørsmål ved hvorfor et sentralt verktøy i arbeidet med å håndtere denne type saker (ratifiseringen av Haagkonvensjonen), kom på plass så sent.
\end{abstract}

Nøkkelord: India $\cdot$ Russland $\cdot$ Romania $\cdot$ norsk utenrikspolitikk • barnevern

\footnotetext{
^Kontaktinformasjon: Stina Torjesen, e-post: stina.torjesen@uia.no

(C2020 Sunniva Cristina Bragdø-Ellenes og Stina Torjesen. This is an Open Access article distributed under the terms of the Creative Commons Attribution 4.0 International License (http://creativecommons.org/licenses/by/4.0/), allowing third parties to copy and redistribute the material in any medium or format and to remix, transform, and build upon the material for any purpose, even commercially, provided the original work is properly cited and states its license. Citation: Sunniva Cristina Bragdø-Ellenes og Stina Torjesen (2020). Diplomatisk hodebry: internasjonale reaksjoner på utvalgte avgjørelser i norsk barnevern, 78(1): 1-31. http://dx.doi.org/10.23865/intpol.v78.1069
} 


\section{Introduksjon}

Våren 2016 demonstrerte over 8000 personer i elleve land mot det norske barnevernet. I løpet av de siste ti årene har det vært flere saker som har utløst sterke reaksjoner i hjemlandene til utenlandske statsborgere berørt av det norske barnevernets avgjørelser. Høsten 2019 var over tjue saker klaget inn til Den europeiske menneskerettighetsdomstol (EMD). Russland og Romania har også brukt sin taletid i Europarådets parlamentarikerforsamling (PACE) og i Organisasjonen for sikkerhet og samarbeid i Europa (OSSE) til å gi negative beskrivelser av norske barnevernprosedyrer.

Til tross for de diplomatiske utfordringene som Norge har stått overfor, har det vært få analyser av disse fra aktuelle fagmiljøer i Norge. Denne artikkelen bøter delvis på denne mangelen ved å undersøke tre av sakene som har skapt reaksjoner internasjonalt. Sakene vi har identifisert, er knyttet til India (2011), Russland (2014) og Romania (2016). I artikkelen forsøker vi å gi noen tentative svar på hvorfor sakene utløste så sterke reaksjoner. Vi redegjør også for hvordan norske myndigheter håndterte sakene, og hvilke implikasjoner sakene fikk for Norges bilaterale relasjoner med de aktuelle landene.

Et viktig funn i vår undersøkelse er at alle sakene kan knyttes til andre sterke drivkrefter i det aktuelle landet. Det er kombinasjonen av en dramatisk familiehistorie i møte med en større politisk agenda som gjør sakene så kraftfulle og betente i de enkelte landene. I materialet vi legger frem, finner vi også tegn til læring og forbedring i Utenriksdepartementets (UD) håndtering, og også utvikling og forbedring i måten UD har samarbeidet med andre deler av embetsverket på. Vi stiller likevel spørsmål ved hvorfor et sentralt verktøy i arbeidet med å håndtere denne type saker (ratifiseringen av Haagkonvensjonen) kom på plass så sent, og vi diskuterer om dette kan anses som mangel på fokus og strategisk tenkning fra byråkratisk og politisk toppledelse.

Dette er en begrenset og tentativ analyse basert på en gjennomgang av tre saker (caser). Kriteriene for utvelgelsen av disse tre sakene er i hvilken grad de fikk stor oppmerksomhet i nasjonale og utenlandske medier. Vi ønsket oss også saker fra tre ulike land og med et visst spenn i tid. Gitt dette har vi altså valgt ut tre saker fra henholdsvis India (2011), Russland (2014) og Romania (2016). Kildene vi har brukt for å belyse sakene, inkluderer gjennomgang av nyhetsartikler, pressemeldinger, forvaltningsdokumenter og internkommunikasjon i UD. I tillegg til dette har vi foretatt en gjennomgang av tilgjengelig juridisk informasjon. Det juridiske innholdet er basert på vanlig juridisk metode hvor særlig lov og forskrift er vektlagt.

Vi har gjennomført åtte intervjuer i forbindelse med denne studien. Disse inkluderer fem samtaler med representanter fra UD, én samtale med representanter fra Sentralenheten for fylkesnemndene for barnevern og sosiale saker, én samtale med en representant fra Barne-, ungdoms- og familieetaten (Bufetat) og én samtale med en representant fra Barne-, ungdoms og familiedirektoratet (Bufdir). Vi har ikke lykkes med å få et intervju med representanter fra Barne- og familiedepartementet (BFD). 
Intervjuene med UD inkluderte samtaler med representanter i Oslo som dekket feltene kommunikasjon eller de ulike landene/regionene som sakene tilhørte. Vi gjennomførte også intervjuer med ambassadør, ambassaderåd og/eller ambassadesekretær som hadde særlig ansvar for sakene vi har sett nærmere på, og som tjenestegjorde på ambassaden i tidsrommet sakene utspant seg. Halvparten av intervjuene ble gjennomført i Oslo, resten via telefon.

Det er en klar skjevhet i kildene vi baserer analysen vår på. Nyheter, presse og dokumenter er hovedsakelig norske eller fra andre vestlige kilder. Intervjuene er kun med representanter fra norske myndigheter og inkluderer ikke perspektiver fra mennesker som har vært engasjert i eller direkte berørt av sakene. De fleste samtalene har også vært på mellomleder- eller operativt nivå, ikke toppledernivå. En sammenlikning av tre saker gir dessuten et relativt snevert grunnlag for analyse. Beskrivelsen av hendelsene i hver sak er også begrenset på grunn av personvern. Et viktig hensyn har vært ikke å bidra til mer informasjon og oppmerksomhet rundt familiene og barna, da dette kan påføre ytterligere belastninger og således bryte med grunnleggende forskningsetiske prinsipper (jf. pkt. 14 og 15 i Forskningsetiske retningslinjer for samfunnsvitenskap, humaniora, juss og teologi). Vi fremstiller dermed faktum i saken kun med utgangspunkt i allerede offentlig tilgjengelig materiale.

Sakene fra Romania og India er relativt godt opplyst via offentlig tilgjengelige kilder, mens Russland-saken fra 2014 er mindre belyst. Det er for eksempel ikke mulig å vite hva endelig avgjørelse i saken var. Vi velger bevisst å ikke oppdrive ytterligere informasjon om dette. De forskningsetiske retningslinjene ber om at det vises særlig hensyn til barn (pkt. 14), og at forskere skal vise respekt for individets privatliv og familieliv (pkt. 15). Vi anser at det vil være uetisk å bidra til at ytterligere informasjon om familienes historie blir gjort tilgjengelig. De involverte barna synes best tjent med at minst mulig informasjon om dem er tilgjengelig i det offentlige som, og vi velger å ta særlig hensyn til dette. Her kan det også være på sin plass å understreke at tema for denne artikkelen er internasjonale reaksjoner på barnevernets avgjørelser og håndteringen av disse reaksjonene. Selve forløpet i sakene, inkludert barnevernets og fylkesnemndenes avgjørelser og fremgangsmåte, er ikke det sentrale temaet i vår analyse.

Gitt skjevhetene og begrensningene i materialet vårt, må vi være svært varsomme med slutningene vi kan trekke. Analysen bygger på og gjengir norske byråkraters perspektiver på de utfordringene som kontroversielle avgjørelser i barnevernet har medført. Vi mener dette i seg selv er et interessant og relevant empirisk materiale som gir viktig innsikt, men vi understreker at dette ikke er et helhetlig bilde. En mer fullstendig studie ville ha krevet innhenting og bruk av flere kilder fra de aktuelle landene. Dette har ikke har vært mulig innenfor rammen av tid og ressurser vi har hatt til disposisjon for denne studien.

Spørsmålet om hvorfor sakene har utløst så sterke reaksjoner, danner en rød tråd gjennom teksten. Vi begynner artikkelen med å gi et oversiktsbilde over 
gjeldende regler og praksis på feltet i henhold til norsk lov, samt sammenligne aspekter ved barnevernpraksis i Norge og enkelte andre vestlige land. Etter denne mer generelle rettslige og forvaltningsmessige gjennomgangen beskriver vi sentrale hendelser og reaksjoner i de tre sakene. Disse beskrivelsene danner så grunnlaget for en analysedel hvor vi identifiserer fellestrekk og ser på mulige grunner til at sakene ble så betente. Vi avslutter artikkelen med noen observasjoner rundt norske myndigheters håndtering, det norske lovverket og den større politiske konteksten sakene utspiller seg i.

\section{Omsorgsovertagelser i Norge og internasjonalt}

Utenlandske reaksjoner på enkelte norske barnevernsaker kan gi inntrykk av at det norske barnevernet har lavere terskel for å gripe inn med omsorgsovertagelse enn barnevernet i andre land. Ser vi på andelen barn som er plassert utenfor familien i regi av barnevernet, så ligger Norge høyt sammenlignet med USA, Irland og England, men på omtrent samme nivå som Tyskland, Sveits og Finland. Norge har imidlertid en høy andel barn som er ufrivillig plassert utenfor hjemmet. ITyskland, Sveits og Finland er henholdsvis 90, 61 og 81 prosent av barna som er plassert utenfor hjemmet, frivillige plasseringer, mens andelen er 29 prosent i Norge. Dette er tall som kan tillegges liten vekt fordi alle varige omsorgsovertagelser i det norske barnevernet må avgjøres av fylkesnemnda for barnevern og sosiale saker (fylkesnemnda, se nærmere beskrivelse i neste punkt), og derfor registreres de som ufrivillige plasseringer (Burns, Pösö \& Skivenes, 2016, s. 57). Saksbehandlingen i fylkesnemnda er en partsprosess hvor foreldre og barn over 15 år er representert med advokat og er motparter til barneverntjenesten, som også er representert med advokat. Foreldre som samtykker til barneverntiltak, vet normalt at barneverntjenesten på visse vilkår har myndighet til å tvangsgjennomføre midlertidig plassering utenfor hjemmet, og at barneverntjenesten kan bringe sak om varige tiltak inn for fylkesnemnda. Selv om det foreligger et samtykke, kan det derfor være problematisk å kategorisere så inngripende tiltak som frivillige. Dette er en viktig del av bakgrunnen for at varige omsorgsovertagelser ikke kan baseres på samtykke, men må avgjøres av et uavhengig organ og etter en topartsprosess som oppfyller strenge krav til prosessuell rettssikkerhet. Tallene sier altså ikke nødvendigvis så mye om hvorvidt plasseringene faktisk er frivillige eller ikke.

Det er hevdet, blant annet i avisoppslag om barnevernsakene som er valgt ut til denne artikkelen, at enkelte omsorgsovertagelser som involverer utenlandske foreldre, beror på kulturforskjeller som det norske barnevernet og norske beslutningstagere ikke forstår (Paulsen, Thorshaug \& Berg, 2014; Berg et al., 2017). Vilkårene for omsorgsovertagelse $\mathrm{i}$ barnevernloven inneholder ingen eksplisitt henvisning til kultur, men det gjør kriteriene for valg av fosterhjem: «Det skal også tas tilbørlig hensyn til at det er ønskelig med kontinuitet i barnets oppdragelse, og til barnets etniske, religiøse, kulturelle og språklige bakgrunn» (barnevernloven $\ 4-15$ 
første ledd). ${ }^{1}$ I forslaget til ny barnevernslov er det foreslått en overordnet bestemmelse som presiserer at barnets og foreldrenes etniske, religiøse, kulturelle og språklige bakgrunn er relevante momenter i vurderingen av barnets beste (NOU 2016: 16, s. 271, 37). Barnevernslovutvalget har ikke funnet grunn til å fremheve språklige, religiøse og kulturelle rettigheter særskilt andre steder i loven. Barneverntjenesten skal sikre barns rettigheter uavhengig av forskjeller i kultur, religion og annen bakgrunn, og kommer barns rett til forsvarlig omsorg i konflikt med deres bakgrunn, må denne vike (NOU 2016: 16, s. 27, 36). Dette rettslige utgangspunktet sier likevel lite om barnevernets faktiske kompetanse om andre kulturer, og om hvordan forskjeller i bakgrunn kan påvirke blant annet omsorgsutøvelse. ${ }^{2}$ Økt kunnskap om minoritetsrelaterte problemstillinger er anbefalt som tiltak innad i barneverntjenesten, samtidig som andre har påpekt at kulturforståelse bare er én av mange faktorer som barnevernet må ta med i vurderingsgrunnlaget - og at dette ikke bør overskygge betydningen av sosiale forskjeller (Berg et al., 2017, s. xi, 2, 3 med videre henvisninger).

Det er en vesentlig større andel innvandrerbarn som mottar hjelpetiltak fra barnevernet, sammenlignet med norske, men forskjellene reduseres når det kontrolleres for sosioøkonomiske faktorer og sivilstatus (Berg et al., 2017). Blant barn med omsorgstiltak var det imidlertid liten forskjell mellom andelen barn med innvandrerbakgrunn og resten av befolkningen. Andelen norskfødte med innvandrerbakgrunn ligger noe lavere enn befolkningen uten innvandrerbakgrunn, mens andelen barn født i utlandet av to utenlandske foreldre, ligger noe høyere. Det er dessuten store forskjeller mellom landene innvandrerne kommer fra. Et interessant trekk i denne sammenhengen er at de gruppene som har fătt mest oppmerksomhet i media (familier fra Polen, Russland og India), ikke er blant dem med spesielt høy andel omsorgsovertagelser. Den største innvandrergruppen i Norge (fra Polen) ligger for eksempel under gjennomsnittet i befolkningen når det gjelder omsorgsovertagelser. Den gruppen hvor andelen omsorgsovertagelse er høyest, er blant norskfødte barn med én forelder født i utlandet (Berg et al., 2017). ${ }^{3}$

\footnotetext{
${ }^{1}$ Det samme gjentas i rundskrivet punkt 5.2 og følger av FNs konvensjon om barnets rettigheter art. $20 \mathrm{om}$ vektlegging av kontinuitet i barnets oppdragelse og hensynet til barnets etniske, religiøse, kulturelle og språklige bakgrunn ved tiltak etter en omsorgsovertagelse; Se også art. 30 om rett til kultur for minoriteter og urbefolkning; Se også FNs konvensjon av 16. desember 1966 om økonomiske, sosiale og politiske rettigheter (SP) art. 27. Bestemmelsene er drøftet i en masteroppgave av Lineikro (2017). En av Lineikros konklusjoner er for øvrig at hun savner en vurdering av hvilke tiltak som kan iverksettes for å ivareta retten etter barnekonvensjonen art. 30 etter fosterhjemsplassering, og at barns rett til kultur i forbindelse med fosterhjemsplassering blir en formalitet så lenge det verken finnes tilfredsstillende fosterhjem eller andre tiltak som iverksettes (s. 50).

${ }^{2}$ Barnevernslovutvalget mener da også at kultursensitivitet i barnevernets arbeid primært bør fremmes gjennom andre virkemidler enn lovgivning, (NOU 2016: 16, s. 36).

${ }^{3}$ Blant barn med innvandrerbakgrunn er det særlig gruppen barn født i Norge av innvandrerforeldre som trekker snittet ned for andelen innvandrerbarn som er omsorgsovertatt (Kalve \& Dyrhaug, 2009, s. 4, 29); Se tall for 2012 inntatt i NOU 2016: 16, s. 34 med henvisning til SSB.
} 
De sakene vi ser nærmere på i denne artikkelen, gjelder alle de tre kategoriene innvandrerbarn. I Romania-saken er far rumensk, mor er norsk, og barna er født i Norge, altså innenfor kategorien med høyest andel omsorgsovertagelser. For kategorien østlige EU, som rumenske barn eller barn født i Norge av rumensk mor tilhører, er andelen omsorgsovertatte barn imidlertid om lag halvparten av andelen for befolkningen uten innvandrerbakgrunn. I India-saken er foreldrene født i utlandet, men minst ett av barna er født i Norge. I Russland-saken er foreldrene født i utlandet, men vi kan ikke, ut fra de kildene vi har adgang til, si med sikkerhet hvor barnet er født. Hverken blant befolkningen fra India, Russland eller østlige EU-land er det altså spesielt høy andel omsorgsovertagelser (Berg et al., 2017, s. 44-45, 108).

Som nevnt innledningsvis har EMD den siste tiden tatt til behandling hele ni saker som gjelder barnevern, mot Norge. Høsten 2018 er avgjørelse falt i fire av sakene. ${ }^{4}$ I de første sakene som ble avgjort, kom EMD til at det ikke forelå konvensjonsbrudd. ${ }^{5}$ I den fjerde saken ble Norge dømt for manglende kontakt mellom en romkvinne og hennes barn, og kvinnen ble tilkjent 25000 euro i erstatning. ${ }^{6}$ Tsjekkia og Slovakia har bedt om å intervenere som tredjepart i alle de ni klagesakene, selv om ingen av klagesakene berører tsjekkiske eller slovakiske statsborgere. Videre er en av de ni sakene etter dissens videresendt til EMDs storkammer, hvor en dom ventelig vil foreligge i 2019. I forbindelse med denne storkammerbehandlingen har det kommet tredjepartsintervensjoner fra fire land (Bulgaria, Belgia, Tsjekkia og Slovakia). Marius Emberland, advokat hos Regjeringsadvokaten, bemerker at «[d] et er høyst uvanlig, og nærmest enestående i EMDs historie, at EMKs medlemsstater intervenerer iht. EMK artikkel 36 nr. 2 i den hensikt å gå mot en annen medlemsstats interesser». Italia, Danmark og Storbritannia har samtidig intervenert til fordel for Norge. Denne situasjonen understreker grunnleggende uenigheter knyttet til barn, barnevern og familieliv mellom stater i Europa, og da særlig mellom stater i nord og vest versus stater i øst og sør (Emberland, 2018, s. 583-584).

Internt i Norge pågår det også en diskusjon om det norske barnevernet. På et grunnleggende nivå må det kunne sies å være en utstrakt enighet om hovedtrekkene ved dagens barnevern. Barnevernslovutvalgets forslag til ny barnevernlov innebærer heller ikke et brudd med hovedlinjene i gjeldende lov, men tilpasser loven til endringer i samfunnet og familiemønstrene som har funnet sted siden gjeldende lov

\footnotetext{
${ }^{4}$ Saker nr. 64808/16, 37283/13, 60371/15, 43701/14, 2822/16, 27496/15, 39710/15, 15379/16 og 14652/16. Se for øvrig Emberland, 2016, s. 329-330.

${ }^{5}$ Klager i saken, en norsk kvinne, hadde to sønner som var halvbrødre. Den eldste gutten (født i 2008) ble plassert i fosterhjem hos klagers mor og stefar da han var to år. Klager anførte at plassering av hennes yngste sønn (født i 2012) i et annet fosterhjem enn hennes eldste - og utenfor familien - utgiorde et brudd på EMK art. 8, men fikk altså ikke medhold; Case of M.L. v. Norway 7.7.2017 (43701/14); Se også Case of Strand Lobben and others v. Norway 30.11.2017 (37283/13), som gjaldt tvangsadopsjon. I denne saken var det dissens, og saken er sluppet inn til behandling i EMDs storkammer; Se også Case of Mohamed Hasan v. Norway 26.4.2018 $(27496 / 15)$.

${ }^{6}$ Case of Jansen v. Norway 6.9.2018 (2822/16).
} 
trådte i kraft i 1992. Samtidig er det altså pågående debatter om barnevernets arbeid og kompetanse. I 2015 skrev en gruppe fagfolk og advokater et opprop med tittelen «Bekymringsmelding om barnevernet». 160 advokater, fastleger, barnevernspedagoger, lærere, journalister og andre skrev under oppropet (Thune et al., 2015; Helmikstøl, 2015). Barnevernets praksis i møte med andre kulturer, da særlig asylsøkere og innvandrere, har i flere år vært et diskutert tema og et område hvor barnevernet har møtt kritikk (NOU 2012: 5, s. 57; Paulsen, Thorshaug \& Berg, 2014, s. 5). Nettopp økt innvandrerbefolkning og økt arbeidsinnvandring innenfor EØS-området er samfunnsforhold som Barnevernslovutvalget påpeker har endret seg siden dagens lov ble vedtatt, og som har aktualisert utfordringer ved kulturelle forskjeller i omsorg for barn (NOU 2016: 16, s. 27-28). Sakene vi belyser i denne artikkelen utspiller seg dermed i en tid og i en kontekst hvor det stilles spørsmål ved inngrep i forholdet mellom barn og foreldre, og ved hvordan barnevernet skal fungere for å ivareta barn med fremmedkulturell bakgrunn på best mulig måte.

\section{Norsk lov: omsorgsovertagelse og midlertidig plassering av barn}

Den norske barnevernlovens bestemmelser om tjenester og tiltak, gjelder for barn som har vanlig bosted og oppholder seg i Norge. For barn som oppholder seg i Norge, men som har vanlig bosted i en annen stat, gjelder deler av lovens bestemmelser (blant annet om hjelpetiltak og midlertidig plassering utenfor hjemmet), mens reglene om omsorgsovertagelse og plassering av ungdom på institusjon også gjelder for barn som har vanlig bosted i Norge, men som oppholder seg i en annen stat. ${ }^{7}$ Barnevernloven hjemler en rekke tjenester og tiltak rettet mot barn og foreldre, og de aller fleste av disse krever samtykke fra foreldrene eller fra større barn, for eksempel veiledning og fattigdomsreduserende tiltak. Et av de mest inngripende tiltakene er omsorgsovertagelse som innebærer at bostedskommunen overtar omsorgen for et barn. Normalt plasseres da barnet i et fosterhjem som utøver den daglige omsorgen på vegne av barneverntjenesten. En avgjørelse om omsorgsovertagelse treffes av fylkesnemnda for barnevern og sosiale saker, som det i alt finnes tolv av. ${ }^{8}$ Fylkesnemndene fungerer som spesialdomstoler for barnevernsaker. De er statlige, domstollignende og uavhengige forvaltningsorganer som ikke kan instrueres i enkeltsaker. Fylkesnemndene er også uavhengige av barneverntjenesten. Sentralenheten for fylkesnemndene for barnevern og sosiale saker leder og administrerer de tolv fylkesnemndene og er et statlig organ underlagt Barne- og familiedepartementet.

For at et barn skal kunne plasseres i fosterhjem, må barneverntjenesten forberede og sende inn en begjæring om omsorgsovertagelse til fylkesnemnda. I fylkesnemnda

\footnotetext{
${ }^{7}$ Lovens bestemmelser om tjenester og tiltak gjelder også for barn som er flyktninger eller internt fordrevne, eller når barnets vanlige bosted ikke lar seg fastsette, jf. barnevernloven $\ 1-2$.

${ }^{8} \mathrm{Hver}$ av fylkesnemndene for barnevern og sosiale saker har ett eller to fylker som geografisk kompetanseområde.
} 
administreres en partsprosess hvor barn over 15 år og foreldrene får oppnevnt advokat(er) på statens bekostning og har rett til innsyn i dokumentene i saken og til å uttale seg om disse og saken for øvrig. ${ }^{9}$ Etter en forberedende fase på to-tre måneder møtes partene i fylkesnemnda til forhandlingsmøte. Med unntak av midlertidige avgjørelser er hovedregelen at fylkesnemnda settes med en leder som er jurist, en psykolog og et legmedlem. I kompliserte saker kan antallet økes med en ekstra fagkyndig og et ekstra legmedlem. Det er nemndsmedlemmene i den enkelte sak som har ansvar for at saken er tilstrekkelig og forsvarlig opplyst.

Prosessen i fylkesnemndene ligner prosessen for tingretten. Forhandlingsmøtet i nemnda strekker seg vanligvis over to-tre dager og følger formen på en hovedforhandling i domstolene, som blant annet innebærer at partene forklarer seg, og at begge sider fører vitner (Fylkesnemndene, 2015, s. 7). ${ }^{10}$ Fra en sak om omsorgsovertagelse kommer inn til fylkesnemnda og til den er avgjort, går det gjennomsnittlig omtrent 80 dager (Fylkesnemndene, 2015, s. 8). Dersom barneverntjenesten vurderer at det er fare for at et barn kan bli vesentlig skadelidende ved å forbli i hjemmet så lenge, og at et midlertidig vedtak er til barnets beste, kan det treffes akuttvedtak som innebærer at barnet blir fjernet fra familien på kort varsel (barnevernloven $\$ \int 4-6$ andre ledd og 4-1). I 2014 ble cirka 1500 barn akuttplassert på bakgrunn av fare for å bli vesentlig skadelidende ved å forbli i hjemmet (NOU 2016: 16, s. 171). ${ }^{11}$ Dette er en type tiltak som også kan settes i verk overfor barn som har fast bosted i et annet land, men som oppholder seg i Norge.

Akuttvedtak kan komme overraskende på foreldrene og kan være dramatiske. I noen tilfeller varsles ikke foreldre før barnevernet tar med seg barnet, for eksempel ved risiko for at foreldrene utsetter barnet for ekstra fare når de får vite om akuttiltaket, som fare for hevn mot barnet, eller for at foreldrene vil rømme til utlandet med barnet. Slike midlertidige vedtak innebærer vanligvis at barnet plasseres $i$ en beredskapsfamilie (en «fosterfamilie» som har plasseringer på kort varsel som oppgave) for en kortere periode. Akuttvedtaket kan bare opprettholdes så lenge vilkårene er oppfylt, men ikke lenger enn seks uker, med mindre barneverntjenesten fremmer ordinær sak for fylkesnemnda innen denne fristen. I så fall kan akuttplasseringen opprettholdes til en ordinær omsorgsovertagelsesak er avgjort i fylkesnemnda (barnevernloven $\int 4-6$ fjerde ledd). Akuttvedtakene skal undergis en nokså summarisk

\footnotetext{
${ }^{9}$ Foreldre har som hovedregel felles advokat, med mindre det er interessekonflikt mellom dem.

${ }^{10}$ Vitnene er vanligvis personer som kan si noe om foreldrenes og barnets/barnas fungering, som ansatte i barnehage og helsetjeneste, lærere i skole eller andre som kjenner familien. Ikke sjelden har en sakkyndig (ofte en psykolog) vurdert foreldrenes omsorgsevner og barnets fungering, og vedkommende stiller i så fall også som vitne. For barn som er fylt syv år, og for yngre barn som er i stand til å danne seg egne synspunkter, men som er under 15 år og dermed ikke utøver partsrettigheter selv, oppnevnes en egen talsperson som skriver en rapport om sin kontakt med barnet, og som også stiller som vitne i nemnda (barnevernloven $₫ 6-3$ ).

${ }^{11}$ Barna utgjør 1,3 promille av befolkningen i alderen 0-17 år (Bufdir Statistikk og analyse, Barnevern 2017).
} 
godkjenning av fylkesnemnda, og kan påklages til fylkesnemnda. En fylkesnemndsleder må avgiøre klagesaken etter et forhandlingsmøte som varer omtrent en halv dag, og formen er enklere enn i de ordinære sakene (barnevernloven $\$ ₫$ 7-22 og 7-23). Barneverntjenesten hadde truffet akuttvedtak i alle de tre sakene vi ser på i denne artikkelen.

Mens beviskravet i de fleste ordinære saker er vanlig sannsynlighetsovervekt, kan kravet til sannsynlighet variere i akuttsakene. ${ }^{12} \mathrm{Er}$ det fare for svært store skader, kan det for akuttiltak være et lavere krav til sannsynlighet enn 50 prosent (Oppedal, 2008, s. 150 flg.). ${ }^{13}$ Vilkårene for omsorgsovertagelse og vilkårene for akuttplassering er forskjellige. For at barneverntjenesten skal kunne overta omsorgen for barn og (vanligvis) plassere dem i fosterhjem, må ett av de fire alternative vilkårene for omsorgsovertagelse i barnevernloven $₫ 4-12$ være oppfylt. Vilkårene som oftest anføres, er at det må foreligge «alvorlige mangler ved den daglige omsorg som barnet får, eller alvorlige mangler $i$ forhold til den personlige kontakt og trygghet som det trenger etter sin alder og utvikling» (barnevernloven $₫ 4-12$ bokstav a). Det første av disse to alternativene brukes, enkelt uttrykt, særlig om materielle mangler, mens det siste brukes om mangler knyttet til foreldres personlighet og evner, for eksempel deres psykologiske eller kognitive situasjon, og er det som oftest anføres. ${ }^{14}$ Det er ytterligere et vilkår for omsorgsovertagelse at mindre inngripende tiltak, typisk hjelpetiltak, ikke kan skape tilfredsstillende forhold for barnet, og en omsorgsovertagelse

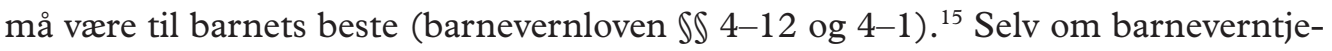
nesten ofte prøver hjelpetiltak før de går til sak om omsorgsovertagelse, innebærer ikke vilkåret at dette faktisk må ha vært forsøkt. Hvis omsorgssvikten er av en slik karakter at hjelpetiltak ikke vil veie opp for, for eksempel, tungt narkotikamisbruk, seksuelle overgrep eller svært alvorlig psykisk sykdom, kan omsorgsovertagelse være det eneste tiltaket barneverntjenesten setter inn.

Ved akuttplassering og plassering etter omsorgsovertagelse etter ordinært vedtak i fylkesnemnda skal henholdsvis barneverntjenesten og fylkesnemnda beslutte hvor

\footnotetext{
${ }^{12}$ Ved ett av de fire alternative vilkårene for omsorgsovertagelse er beviskravet høyere, se barnevernloven $₫ 4-12 \mathrm{~d}$ ).

${ }^{13}$ Tanken er da at det er bedre å fjerne barnet midlertidig fra en potensielt svært skadelig situasjon, og så heller tilbakeføre hvis det viser seg at faren ble feilvurdert, enn å tillate en liten sannsynlighet for at svært alvorlig skade skal skje, for eksempel et nytt seksuelt overgrep eller bortføring av barnet. ${ }^{14}$ Omsorgssvikt som fører til omsorgsovertagelse, kan gjelde mange forhold. Inn under nevnte vilkår kan alt fra narkotika- og annet misbruk av rusmidler til foreldre med psykiske problemer eller kognitive svakheter som gjør dem ute av stand til å følge opp barnet slik at det utvikler seg tilfredsstillende, kvalifisere. Enkelte foreldre med store egne problemer skaper så mye forvirring og utrygghet for sine barn at barnet ikke utvikler seg slik de skal - og da med så store negative avvik at det regnes som alvorlige omsorgsmangler. Materielle mangler alene (fattigdom) kan jo avhjelpes på andre måter, særlig med økonomisk støtte.

${ }^{15}$ Ved anvendelse av bestemmelsene i dette kapitlet skal det legges avgjørende vekt på å finne tiltak som er til beste for barnet. Hensynet til barnets beste følger også av Grunnloven $₫ 104$ og Barnekonvensjonen art. 3.
} 
mye samvær foreldrene skal ha med barna, og eventuelt også andre vilkår knyttet til samværet, for eksempel om det skal være tilsyn under samværene (barnevernloven $\S 4-19)$. I to av de tre sakene vi ser på i denne artikkelen (India og Romania), vet vi at foreldrene ble gitt korte samvær med tilsyn.

Når det er overveiende sannsynlig at foreldrene kan gi barnet forsvarlig omsorg, og barnet ikke har fått slik tilknytning til mennesker og miljø der det er plassert at tilbakeføring kan føre til alvorlige problemer for barnet, skal barnet tilbakeføres til foreldrene. ${ }^{16}$ Har barnet utviklet slik tilknytning, er det i tillegg et vilkår for ny sak om tilbakeføring at en vesentlig endring har funnet sted (barnevernloven $\ 4-21$ ).

Hvis foreldrene eller barnevernet er uenige i fylkesnemndas vedtak om omsorgsovertagelse, kan det bringes inn for tingretten. Tingretten settes da med en fagkyndig meddommer og et legmedlem, og ofte oppnevnes det ny sakkyndig til å vurdere saken. Omtrent halvparten av fylkesnemndsvedtakene i hoved- og klagesaker ble bragt inn for tingretten. ${ }^{17}$ Det er ikke vanlig at overprøving i tingretten fører til vesentlige endringer i fylkesnemndas vedtak (Fylkesnemndene, 2015, s. 24).

Dom fra tingretten kan ankes videre til lagmannsretten, men ettersom saken allerede er behandlet $i$ to instanser, blir det bare gitt samtykke til behandling hvis saken oppfyller visse vilkår: Den må enten ha betydning for andre saker, det må være kommet frem nye opplysninger, det må være vesentlige svakheter ved tingrettens avgjørelse eller saksbehandling, eller tingretten må ha vedtatt tvang som ikke ble vedtatt av fylkesnemnda (tvisteloven $₫ 36-10$ tredje ledd). Omtrent 15 prosent av sakene som årlig blir anket fra tingrett til lagmannsrett, anses å oppfylle ett av disse vilkårene og slipper gjennom til behandling. I Høyesterett avgjøres årlig anslagsvis ti barnevernsaker, de fleste om prosessuelle spørsmål. ${ }^{18}$

Av sakene vi ser på i denne artikkelen, vet vi at India-saken gikk til tingretten. Romania-saken synes å ha blitt løst rett i forkant av at hovedsaken skulle opp i tingretten. Ut fra de tilgjengelige kildene kan vi ikke si om Russland-saken ble behandlet i tingretten.

All informasjon i barnevernsaker er taushetsbelagt. Heller ikke selve klientforholdet mellom privat part og barnevernet eller fylkesnemnda kan røpes (forvaltningsloven $\ 13$; barnevernloven $\ 6-7$ ). Voksne private parter bestemmer selv hvordan de vil håndtere informasjon som gjelder dem. Etter å ha hørt barnets oppfatning bestemmer den voksne også over informasjon som gjelder egne, mindreårige barn (barneloven $₫ 31$ ). Taushetsbelagte opplysninger om andre private parter, for

\footnotetext{
${ }^{16}$ Barnevernet har plikt til å vurdere dette løpende, mens foreldrene har rett til å få spørsmålet vurdert av fylkesnemnda tidligst ett år etter saken sist ble avgjort der (barnevernloven $\ 4-16$ ).

${ }^{17} \mathrm{Av}$ totalt nesten 4700 avgjørelser i fylkesnemndene (alle typer saker med unntak av de som ble trukket, hevet eller avvist) ble nærmere 1500 bragt inn for tingretten. Saker om godkjenning av akuttvedtak bringes ikke inn for retten, og fratrukket disse sakene var det totale antallet ca. 3000 fylkesnemndsaker (Fylkesnemndene, 2015, s. 11).

${ }^{18}$ I 2015 ble ca. 350 dommer fra tingrettene anket inn for lagmannsretten (NOU 2017: 8, s. 105).
} 
eksempel den andre forelderen i en sak, kan en privat part i saken bare bruke i den utstrekning det er nødvendig for å vareta egen interesse i saken (forvaltningsloven $\S 13 \mathrm{~b}$ siste ledd første punktum).

Overfor media kan private parter legge frem sin versjon av barnevernsaken, mens barnevernansatte eller andre offentlige tjenestemenn er pålagt begrensninger. Selv om barneverntjenesten har fått private parters samtykke til å gi ut taushetsbelagte opplysninger, har de ansatte i barneverntjenesten aldri plikt til å uttale seg. Hensynet til barnet tilsier i mange tilfeller at barnevernet ikke kommenterer enkeltsaker i media, selv om foreldrene har samtykket eller gjort opplysninger alminnelig kjent. Barneverntjenesten vil likevel ofte kunne korrigere feil ved faktiske opplysninger som er offentliggjort, og vil kunne gi uttrykk for at det er sider ved saken som ikke er kommet frem (barnevernloven $₫ 6-7$ siste ledd; Q-24/2005 punkt 6.2.3).

Føringene som taushetsplikten gir, er tydelig til stede i de tre sakene vi ser på i denne artikkelen. Familiene og deres støttespillere gir ganske rikelig med informasjon til media, mens norske myndigheter bare uttaler seg generelt om barnevernets praksis og sier lite eller ingenting om barnet og familiene. En konsekvens av dette, som vi diskuterer nedenfor, er at både det aktuelle landets myndigheter og det aktuelle landets medier må basere seg på informasjon fra kun privat part når de engasjerer seg i saken.

\section{Tre barnevernsaker}

I det følgende beskriver vi tre barnevernsaker som har utløst sterke internasjonale reaksjoner. Alle tre sakene har sitt utgangspunkt i det lovverket og de prosedyrene vi har beskrevet over. Vi har valgt lik struktur for redegjørelsen for de tre sakene. Først omtaler vi selve saken og den formelle behandlingen av den, så beskriver vi reaksjoner i hjemlandet og norske myndigheters respons. Vi avslutter med en illustrasion av relevant politisk kontekst som saken utspilte seg i, og nevner mulige implikasjoner for Norges bilaterale forhold til den aktuelle staten. Kildene våre gir også mulighet til å si litt om utviklingen i det norske byråkratiets håndtering av denne type saker, og vi avslutter den empiriske delen av artikkelen med en beskrivelse av denne utviklingen.

\section{India-saken 20II-20I2}

Saken omhandlet et indisk ektepar bosatt i Stavanger med to barn (ett og tre år). Far arbeidet som geofysiker, og mor var hjemmeværende. Foreldrene ble fratatt omsorgen for barna i mai 2011. Omplasseringen skjedde etter et akuttvedtak. Den videre saksgangen inkluderte en klage på akuttvedtaket i juli 2011 (ikke tatt til følge), vedtak om omsorgsovertagelse i fylkesnemnda 29. november 2011 og senere behandling i Stavanger tingrett. Saken ble løst i Stavanger tingrett i april 2012 ved at barna ble fosterhjemsplassert hos fars bror, bosatt i India. Onkelen reiste tilbake til India med barna like etter kjennelsen i tingretten (TV2, 2012). 
Hendelsene trigget sterke reaksjoner i India. De første protestene kom i form av små demonstrasjoner utenfor det norske konsulatet i Kolkata høsten 2011. Indisk UD fanget opp denne saken og initierte så en formell dialog med den norske ambassaden i desember 2011. Det indiske utenriksdepartementet utga også seks pressmeldinger om saken. Pressemeldingene var mer uttalt kritiske enn det som ble uttrykt i den direkte kontakten mellom utenriksdepartementene i Norge og India (intervju med representant fra norsk UD, 29. mars 2017). I en kritisk fase ble den norske Ministerråden (i egenskap av å være charge d'affaires i ambassadørens reisefravær) kalt inn til møte med den indiske utenriksministeren $i$ hans private bolig, og Norges og Indias utenriksministere kommuniserte via telefon samme kveld (ibid.).

Protestene i Kolkata vedvarte gjennom hele perioden saken utspilte seg, og det var også enkelte protester i New Delhi. Det var et bredt spekter av grupper som deltok i protestene, selv om Bharatiya Janata Party (BJP) sin kvinnegruppe syntes å ha en særlig fremtredende rolle. Protestene trakk aldri store menneskemengder, men var hyppige (ibid.) Saken ble også mye omtalt i riksdekkende medier, inkludert i nyhets- og talkshowsendinger på sentrale TV-kanaler. Innholdet og budskapet i mange av nyhetssendingene var svært ofte uriktig (ibid.). Disse inneholdt typiske påstander om at det å gi barna mat med hendene, eller det å sove sammen med dem, hadde vært utslagsgivende i fylkesnemndas behandling (ibid.; BBC, 2012).

Norske myndigheter valgte å ha tett dialog med indiske myndigheter $i$ håndteringen av saken. Det norske utenriksdepartementet (UD) assisterte også i forberedelsene til et besøk av den indiske utenriksministerens spesialutsending til Stavanger. Dialogene før og under dette besøket synes å ha bidratt til konstruktive forslag rundt hvordan saken kunne tas videre eller løses. Ambassaden brukte også en god del tid på å håndtere media. Norge ga generell informasjon om norsk barnevern til indiske medier og indiske myndigheter, selv om UD aldri, av hensyn til taushetsplikten, kommenterte selve saken. Ambassaden initierte også en dialog med noen utvalgte, seriøse mediehus for å oppfordre til mer nyansert dekning av saken. Dette hadde noe effekt, om enn kortvarig. Jonas Gahr Støre ga dessuten et lengre intervju med en av Indias mest sentrale aviser (intervju med representant fra norsk UD, 29. mars 2017).

Saken forløp på et tidspunkt da det pågikk valgkamp i India. Dette kan ha medvirket til at ulike grupper med politiske bånd engasjerte seg ekstra sterkt i saken. Det kan også ha medvirket til at pressemeldingene fra indisk UD ble noe skarpere enn de ellers kunne ha vært. Som nevnt var kvinnegruppen til BJP en av gruppene som var særlig aktive. Den overordnete retorikken til BJP ved valget var knyttet til et sterkt og stolt India, inkludert viktigheten av indiske tradisjoner. Et indisk foreldrepars utfordringer i møte med tilsynelatende urimelige utenlandske krefter, kan tenkes å ha passet godt inn i denne diskursen. ${ }^{19}$ Mediestormen rundt denne saken var også av

\footnotetext{
${ }^{19}$ Vi har ikke gjort tilstrekkelige undersøkelser til å kunne dokumentere at det er klar kausal sammenheng mellom et ønske om å gjøre det sterkt i valgkampen og engasjement i India-saken. Dette må dermed regnes som en påstand fra forfatternes side.
} 
en slik art at indiske myndigheter i sine offentlige uttalelser aldri ga tydelig støtte til norske myndigheters perspektiver eller budskap i saken - til tross for en konstruktiv bilateral dialog mellom de to landene i håndteringen av saken (intervju med representant fra norsk UD, 29. mars 2017).

Saken påførte ambassaden en betydelig ekstra arbeidsbyrde og var særlig belastende for det norske konsulatet i Kolkata. Utenriksdepartementet laget en egen prosjektgruppe for håndteringen av saken, bestående av medarbeidere $\mathrm{i}$ både Norge og India, inkludert kommunikasjonsmedarbeidere. Dette lettet arbeidspresset på ambassadens personell og gjorde det mulig å opprettholde arbeid og fokus på ambassadens øvrige saker. ${ }^{20}$ Saken ser ikke ut til å ha påvirket norsk-indiske stat-tilstat-relasjoner negativt. Det ble avholdt ti møter med norske ministre eller statssekretærer i perioden saken varte. Dette var regulære politiske besøk som hadde blitt planlagt før India-saken. Saken var dessuten høyt profilert i nasjonale medier, som igjen ga ekstra oppmerksomhet til Norge. Indiske myndigheter ønsket å få til en løsning i saken og var interessert i å møte norske representanter. Dialogen økte graden av innpass og tilgang til de øverste nivåene i indisk politikk og byråkrati og ble vurdert som et positivt diplomatisk element i en ellers uheldig og vanskelig situasjon (intervju med representant fra norsk UD, 29. mars 2017).

\section{Russland-saken 2014}

Saken omhandlet et russisk par bosatt i Tromsø. Paret ble fratatt omsorgen for sin fem år gamle sønn. Barnet ble hentet av barnevernet $\mathrm{i}$ barnehagen etter et akuttvedtak høsten 2014. I den påfølgende ordinære behandlingen av saken i fylkesnemnda ble vedtaket om omsorgsovertagelse vedtatt (itroms.no, 2014). Russlands visekonsul i Nord-Norge, Igor Lapitskiy, møtte senere Fylkesmannen i Troms vedrørende saken. Det er ikke offentlig kjent om vedtaket ble opprettholdt eller senere omgjort.

Saken trigget omfattende reaksjoner i Russland. Den føyet seg også inn i en rekke av lignende norske og finske saker som hadde blitt tatt opp av russisk media og russiske myndigheter. Den russiske presidentens kommissær for barns rettigheter, Pavel Astakhov, fanget raskt opp saken og engasjerte seg sterkt. Astakhov publiserte blant annet flere twittermeldinger som omtalte detaljer i saken. I samme periode uttalte Astakhov seg kritisk også om det finske barnevernet, og påpekte at dette liknet «juvenile terror» (Uutiset, 2014). Et av Astakhovs resonnementer i saken var at land som Norge hadde behov for å utvide sitt genpool, og at det var derfor myndighetene tok russiske barn (intervju med representant for Utenriksdepartementet B, 31. mars 2017). Det russiske utenriksdepartementet engasjerte seg også i saken og la ut informasjon om saken på sine hjemmesider. Denne informasjonen inneholdt, ifølge Det norske utenriksdepartementet, "grovt feilaktige påstander» (Utenriksdepartementet,

\footnotetext{
${ }^{20}$ For øvrig håndterte ambassaden problemene med Telenors lisenser og korrupsjonsanklager parallelt med India-saken.
} 
2015a). Russlands ambassadør til Organisasjonen for sikkerhet og samarbeid i Europa (OSSE) holdt også et innlegg i OSSEs råd i april 2016 der ambassadøren beskyldte norske myndigheter for å intensivere sin kamp mot familien som institusjon, og der han hevdet at barnevernets omsorgsovertagelse i saker med barn av ikke-norsk opphav, grenset til rasisme (Utenriksdepartementet, 2016a).

Saken fikk omfattende dekning i russiske medier, inkludert i flere TV-programmer og et sentralt talkshow. Et russisk TV-team reiste også til Tromsø for å dekke saken. Norske byråkrater oppfattet at Pavel Astakhov hadde en styrende rolle i russiske mediers dekning i denne og liknende saker, særlig i forhold til Putin-vennlige medier som Kanal En (Perviy kanal) og Russia Today (RT) (intervju med representant for Bufetat, 11. desember 2018). Det ble også avholdt demonstrasjoner utenfor den norske ambassaden i Moskva, der om lag 10-20 demonstranter deltok. Korte filmklipp fra demonstrasjonene ble lagt ut på YouTube. Der vises blant annet demonstranter som legger pakker med laks på bakken og tråkker på dem (YouTube, 2014). Ambassaden mottok også mange e-poster og brev hvor det ble uttrykt støtte til foreldrene i saken (intervju med representant for Utenriksdepartementet B, 31. mars 2017).

Norske myndigheter responderte på dette ved å legge ut informasjon om norsk barnevern på ambassadens hjemmesider. Den norske ambassaden i Moskva utarbeidet også en "démarche» hvor de kritiserte russiske myndigheter for å gi feilaktig informasjon om saken i russisk offentlighet, og som ble overrakt Det russiske utenriksdepartementet i et møte høsten 2014 (intervju med representant for Utenriksdepartementet B, 31. mars 2017). ${ }^{21}$ I tillegg ble den russiske ambassadøren i Oslo kalt inn til et møte med statssekretær Bård Glad Pedersen, der liknende protester ble satt frem (Utenriksdepartementet, 2015a).

Mens saken var på agendaen i russiske medier, hadde den norske ambassaden i Moskva dialog med den finske ambassaden for å lære av finske erfaringer med liknende saker. En sentral vurdering for ambassaden var spørsmålet om ambassadens personell burde delta i eller komme med egne bidrag til debatter om saken i russisk media. Her ble det vurdert at dekningen i Russland, inkludert i statlige mediekanaler, var for ensidig. Ambassaden regnet det som usannsynlig at det norske budskapet ville kunne komme tydelig og helhetlig frem, og besluttet dermed å ikke delta (intervju med representant for Utenriksdepartementet $\mathrm{B}, 31$. mars 2017). Norges håndtering skilte seg for øvrig noe fra den finske håndteringen. Finland ble ansett som mer proaktiv enn Norge. Den finske sosialministeren, som snakket flytende russisk, holdt en pressekonferanse i Moskva, og Finland sendte også en barnevernsekspert til den finske ambassaden for å jobbe full tid med barnevernspørsmål i en periode (intervju med representant for Bufetat, 11. desember 2018).

Saken vi omtaler her, utspilte seg $i$ en ellers tøff periode i norsk-russiske relasjoner. Russland hadde $\mathrm{i}$ juni samme år annektert Krimhalvøya og støttet opprørsgrupper i Øst-Ukraina. Norge oppfordret til sanksjoner og deltok også fullt ut

\footnotetext{
${ }^{21}$ En démarche er et politisk skritt eller tiltak.
} 
i gjennomføringene av sanksjonene som ble utarbeidet av EU og USA. Russiske myndigheter hadde generelt en skarp og klar antivestlig retorikk i sine uttalelser, både til et hjemlig publikum og internasjonalt. Med Vladimir Putin som president var vestlig kultur forsøkt svertet ved å implisere dekadanse, manglende familieverdier og hykleri på felter knyttet til menneskerettigheter og bruken av militærmakt. I tillegg til å engasjere seg i den norske barnevernsaken var Astakhov også en tydelig kritiker av amerikanske foreldres adopsjon av russiske barn (RFE/RL, 2013).

Det er verdt å merke seg at Astakhovs engasjement og kritikk av vestlige land begynte flere år før krigen i Ukraina, og også før saken vi ser på i denne artikkelen, utspilte seg. I 2012 troppet for eksempel Astakhov opp med et russisk TV-team på et ressurssenter for adoptivbarn med atferdsproblemer i Montana i USA og satte frem skarp og, ifølge eierne, helt uberettiget kritikk (Daily Mail, 2012). Astakhov synes å ha drevet med en langsiktig kampanje for å diskreditere vestlig adoptiv- og barnevernpraksis. Det kan synes som om Astakhovs engasjement har vært proaktivt og planlagt. Målsettingen synes nettopp å ha vært å ta del i oppbyggingen av Putin-regimets medienarrativ rundt vestlig dekadanse og manglende familieverdier, selv om det bør understrekes at vi ikke har sikre kilder som kan bevise denne antakelsen fra vår side.

Norske byråkrater hadde også merket en tydelig endring i den russiske tilnærmingen til barnevernspørsmål etter at Putin gjeninntok presidentembetet i 2012. Putin styrket ytterligere sin kontroll («maktvertikalen») og graden av lojalitet blant politikere og representanter på en lang rekke felt i denne perioden (Moscow Times, 2012). Dette fikk også konsekvenser innen russisk barnevern. Norske myndigheter observerte en klar endring i denne perioden, med personellutskiftinger og en situasjon der Russlands barnevernfaglige fokus og dialog med norske og andre lands myndigheter ble tonet ned, samtidig som en ny og mer nasjonal retorikk ble tatt uniformt $\mathrm{i}$ bruk av regionale og nasjonale representanter for russisk barnevern (intervju med representant for Bufetat, 11. desember 2018).

Norsk-russiske stat-til-stat-relasjoner synes ikke å ha blitt direkte berørt eller svekket av saken, selv om saken antakelig ga et omdømmetap for Norge i Russland. Ukraina-krisen og sanksjonsregimet var den dominerende saken i denne perioden, og utløste blant annet en reduksjon i den militære dialogen og en opptrapping av russisk patruljering av hav- og luftrom nær Norge. Samtidig så vi et vedvarende og robust samarbeid rundt saker på lavere nivå ("low politics»), som fiskeriforvaltning og miløøarbeid. Enkelte byråkrater registrerer at samarbeidet mellom fagetatene på barnevernområdet også er noe styrket $i$ årene etter 2014, mens andre fremhever redusert kontakt i etterkant av sanksjonene (intervju med representanter for Utenriksdepartementet, 3. mars 2017; intervju med representant for Bufetat, 11. desember 2018).

\section{Romania-saken 2015-2016}

Saken omhandlet et norsk-rumensk ektepar med fem barn, bosatt i Naustdal kommune i Sogn og Fjordane. Far var IT-arbeider fra Romania, og mor var sykepleier fra 
Naustdal. Ved et akuttvedtak ble alle fem barna, inkludert en baby på tre måneder, hentet ut av hjemmet 16 . november 2015. Akuttvedtaket ble først klaget inn for fylkesnemnda og deretter bragt inn for tingretten. Tingretten opprettholdt akuttvedtaket i dom av 5. april 2016, men besluttet å tilbakeføre det minste barnet til foreldrene. Saken om omsorgsovertagelse var berammet til (ordinær) behandling i fylkesnemnda noen uker senere (Utenriksdepartementet, 2016a). I juni 2016 besluttet barneverntjenesten å trekke saken, samtidig som den utarbeidet en handlingsplan sammen med foreldrene. Foreldreparet flyttet senere til Romania med alle fem barna.

Saken utløste en rekke reaksjoner fra den rumenske staten. Den rumenske ambassaden i Oslo var aktivt engasjert på et tidlig tidspunkt. Ambassaden prøvde i flere uker, uten hell, og få på plass et møte med norske barnevernmyndigheter (trolig Barne- og familiedepartementet) for å få mer informasjon i saken. Denne utsettelsen ble oppfattet som uheldig av den rumenske ambassaden (Utenriksdepartementet, 2015b). I Bucuresti ble den norske ambassadøren første gang gjort oppmerksom på saken i en samtale med en høytstående representant fra det rumenske utenriksdepartementet under en formell middag. Ambassaden hadde senere møter med blant annet medlemmer av det rumenske parlamentet og med en rådgiver til presidenten og med statsministerens kontor (intervju med representanter for Utenriksdepartementet A, 31. mars 2017; Utenriksdepartementet, 2017a). Det synes å ha vært en løpende dialog mellom representanter for norsk og rumensk UD i hele perioden. Ingen representanter fra den rumenske staten ønsket å fronte eller bidra med norske perspektiver på saken i rumensk media (intervju med representanter for Utenriksdepartementet A, 31. mars 2017).

Saken ble i januar 2016 løftet opp av en fraksjon i det rumenske parlamentet. En delegasjon på syv parlamentsmedlemmer, alle medlemmer av pinsebevegelsen, besøkte Norge. Delegasjonens deltakere inkluderte Mircea Dolha, visepresident for en formell parlamentskomité for saker knyttet til rumenere i utlandet, samt parlamentsmedlem og tidligere utenriksminister Titus Corlăţean. Gruppen var blant annet i møte med norske stortingsmedlemmer, representanter fra UD, og med Fylkesmannen i Sogn og Fjordane. Besøket inkluderte en tur til Naustdal og en befaring til familiens hus og nabolag (Romanian National News Agency, 2016).

Den rumenske pressedekningen av saken var intens gjennom hele perioden saken utspilte seg, særlig i desember og januar, da den var blant de nasjonale toppsakene. En TV-kanal kjørte direktesendinger som enkelte dager varte i flere timer. Ambassaden mottok også store mengder e-post og julekort (intervju med representanter for Utenriksdepartementet A, 31. mars 2017). Det ble avholdt flere demonstrasjoner i perioden saken var under behandling. Mange av disse var mindre demonstrasjoner som ble holdt flere steder i landet, inkludert i Bucuresti, Cluj-Napoca og Arad. Den mest sentrale markeringen ble holdt 16. april, da 1000 mennesker demonstrerte i Bucuresti, 3000 i Cluj-Napoca og 1800 i Arad (Utenriksdepartementet, 2016b; 2016f).

Saken hadde også en tydelig internasjonal dimensjon. Her var særlig to aspekter viktige. For det første mobiliserte saken i andre land der det nylig hadde vært 
vanskelige, norske barnevernsaker, særlig i Tsjekkia. For det andre var den norskrumenske familien pinsemedlemmer, og saken mobiliserte pinsevenner i Europa, USA og Australia. Samtidig med demonstrasjonen i Bucuresti ble det avholdt demonstrasjoner en rekke andre steder, inkludert for eksempel Wien, Houston og Sydney. I forkant var det varslet om demonstrasjoner på 59 steder i tyve land, men UDs kilder tyder på at det til slutt ble holdt demonstrasjoner i elleve land der i overkant av 8000 mennesker møtte opp (NRK, 2016; Utenriksdepartementet, 2016f). I tillegg er det uklart hvor mange tusen mennesker som totalt sett faktisk møtte opp (intervju med representanter for Utenriksdepartementet A, 28. og 31. mars 2017). I Norge ble det blant annet holdt protester i Stryn og Vennesla.

Den amerikanske pinsemenigheten var aktiv gjennom hele perioden saken varte, også i starten (Utenriksdepartementet, 2017a). Bakgrunnen for protestene fra pinsemenigheter utenfor Norge var at barnevernets inngrep i familien ble sett på som en trussel mot religionsfriheten. Overtagelsen av omsorgen for barna ble oppfattet som et tegn på at paret ble straffet for å ha utøvet sin religion. Mange av demonstrasjonene som ble holdt, ble dermed markeringer av støtte til den norsk-rumenske familien spesielt, men de ga også rom for mer generelle markeringer av pinsemenighetens kamp for religionsfrihet i alle land (Utenriksdepartementet, 2016c).

I tillegg til demonstrasjonene ble det også forfattet et protestbrev underskrevet av 102 jurister, akademikere og politikere fra Australia, Belgia, Romania, Sør-Korea, Storbritannia, Tsjekkia og USA. I brevet hevdes det at omsorgsovertagelsen skjedde på grunn av familiens tro og religiøse verdier. Det påpekes at barna i sine nye fosterfamilier ble frarøvet sin tro. I brevet ble det også argumentert for at barnevernet hadde brutt barnevernloven ved at barnas religiøse identitet ikke var blitt ivaretatt (barnevernloven \4-15), samt at EMK artikkel 8 ("Everyone has the right to respect for his private and family life») ikke var overholdt (Costea, 2016).

Enkelte aktører skiller seg ut som viktige pådrivere i saken. Advokaten Peter Costea spilte en særlig sentral rolle. Costea var pinsevenn og opprinnelig rumensk, men bosatt i Houston i USA. Advokaten viste et sterkt engasjement og var blant annet en av initiativtakerne til brevet, samt deltok på en rekke demonstrasjoner, inkludert i Stryn 16. april 2017. Costea hadde stilt til valg i Europaparlamentet i 2014 og var forventet å stille igjen i 2019. Engasjementet til Costea i saken kan ha gitt ham økt synlighet overfor rumenske velger. Andre særlig engasjerte aktører inkluderte tidligere utenriksminister Titus Corlăţean og eksperten Alexander George. Sistnevnte ga angivelig ut en bok der tittelen signaliserte budskapet «Våre barn i deres fengsler» og «stjålet av barnevernet» (Utenriksdepartementet, 2016d).

Norske myndigheter tok en rekke grep i håndteringen av saken. Den norske ambassaden stilte som nevnt i møter med flere representanter for rumenske myndigheter, blant annet ansatte i det rumenske utenriksdepartementet, representanter for det rumenske parlamentet og presidentens rådgiver. Ambassaden valgte også å bidra med generell informasjon om norsk barnevern til rumenske medier. Dette inkluderte deltakelse i et langt TV-program, der et kort intervju med ambassadøren 
ble klippet inn på en måte som var ufordelaktig og lite samstemt med hovedbudskapet ambassadøren hadde satt frem $\mathrm{i}$ intervjuet (intervju med representanter for Utenriksdepartementet A, 31. mars 2017). Det ble også utgitt en kronikk av Solveig Horne og Elisabeth VikAspaker. Vårt Land dekket saken, og artiklene deres ble oversatt til rumensk av ambassaden og gjort tilgjengelig for et rumensk og internasjonalt publikum. Det var kontakt mellom norske myndigheter og norske pinsemenigheter, og menigheten uttalte seg også positivt om norsk religionsfrihet, blant annet i en pressemelding (intervju med representanter for Utenriksdepartementet A, 28. mars og 31. mars 2017). Uttalelsene ble oversatt til engelsk og rumensk. Utenriksdepartementet mente bidragene var nyttige, samtidig som effekten ble begrenset av mistro til denne type uttalelser. Rumenske mottakere av budskapet antok trolig at uttalelsen var bestilt av den norske staten (ibid.) For øvrig opplevde UDs representanter i Bucuresti det som særlig utfordrende å få formidlet at norske innbyggere har grunnleggende tillit til norske institusjoner, og til at norske tjenestemenn arbeider i henhold til det formelle lovverket og vedtatte prosedyrer. Denne type tillit er i mye mindre grad til stede i Romania, noe som bidro til å gjøre den rumenske opinionen mer mistroisk (ibid; Utenriksdepartementet, 2017a).

Saken utspilte seg i en kompleks kontekst. Den rumenske regjeringen var altså et forretningsministerium, og det pågikk samtidig forberedelser til valg. Rumenske myndigheters evne, eller til tider manglende evne, til å støtte den høye andelen rumenere som lever og arbeider utenfor Romanias grenser, var i tillegg et vedvarende, underliggende tema i rumensk politikk. Saken om den norsk-rumenske familien omhandlet nettopp en (halvt) rumensk familie i utlandet som ble utsatt for press, og den gjorde det særlig opportunt for rumenske myndigheter og politikere å demonstrere engasjement og handling $\mathrm{i}$ saken. Retorikken rundt myndighetenes håndtering ble også oppfattet todelt. Rumenske myndigheter og politikere ga tidvis uttrykk for at det var viktig å etterleve formelle prosedyre og regler i saken. Andre ganger valgte myndighetene å understreke behovet for at saken måtte og kunne ordnes opp i med en ad hoc og uformell inngripen (intervju med representanter for Utenriksdepartementet, 3. mars 2017). På en pressekonferanse i Bucuresti i etterkant av parlamentdelegasjonens reise til Norge, uttalte for eksempel Mircea Dolha følgende: "The situation in Norway is worrisome [...] We have clear signals - we don't want to exaggerate anything, sell illusions - promises that they will issue an internal order to all local authorities to be very careful, because Romanians were not the only to send signals» (Romanian National News Agency, 2016).

Over nevnte vi at pinsemenigheter over hele verden engasjerte seg i saken. Amerikanske pinsemenigheter var særlig aktive. Det norske konsulatet i Houston mottok blant annet en rekke henvendelser fra religiøse grupper. Saken traff en nerve i den kristne høyrefløyen i amerikansk politikk. Bakteppet var en generell oppfatning i mange kristne miljøer om at familieverdier og kristendommen ble angrepet av sekulære krefter i USA og Europa. En av undertegnerne av brevet til statsminister Solberg var Michael Farris, lederen for Home School Legal Defense Association, 
en kristen organisasjon som advarer sterkt mot truslene kristne verdier står overfor. En annen undertegner var Horatio G. Mihet, som er engasjert i Liberty Counsel, en organisasjon definert av liberale miljøer i amerikanske politikk som «a legal organisation advocating for anti-LGBT discrimination under the guise of religious liberty" (Utenriksdepartementet, 2016e).

Protestene mot Norge var koordinert og innebar samarbeid mellom grupper over landegrenser. De samme bildene og budskapene figurerte på like plakater i flere ulike land, særlig på den store protestdagen i april 2016. Sosiale medier var sentrale arenaer (se nedenfor). Ved googlesøk på adressen til flere norske utenriksstasjoner, inkludert den norske ambassaden i Washington, ble adressen koblet til bilder som indikerte problemer med og protester mot norsk barnevern. Norsk UD responderte med å laste opp bilder av det aktuelle ambassadebygget og andre relevante fotografier, slik at barnevernsaken ikke skulle komme opp som første søk i Google (intervju med representanter for Utenriksdepartementet, 28. mars 2017; Utenriksdepartementet, 2017a).

Saken innebar trolig et sterkt omdømmetap for Norge blant enkelte kristne miljøer i USA og Europa og også delvis i den rumenske befolkningen. Dette gjelder sannsynligvis fortsatt. Samtidig opprettholdt Norge og Romania den bilaterale stattil-stat-kontakten, selv om den politiske kontakten ble tonet ned i perioden (Utenriksdepartementet, 2017a). De regelmessige forhandlingene og diskusjonene rundt bruken av EØS-midlene, som er blant de viktigste sakene i norsk-rumenske relasjoner, ble likevel gjennomført på ordinært vis (intervju med representanter for Utenriksdepartementet A, 31. mars 2017).

\section{Utvikling $\mathrm{i}$ håndteringen av internasjonale barnevernsaker}

Over har vi sett på grepene som ble tatt av ambassadene og UD i Oslo for å håndtere de internasjonale barnevernsakene på kort sikt. I tillegg ble det gjort viktige organisatoriske og rettslige endringer i forvaltningen. Her er særlig fire aspekter viktige å trekke frem: En sentral, internasjonal konvensjon ble ratifisert, BFD og Bufdir økte ressursbruken på internasjonale saker, og et rundskriv ble utarbeidet for å gi tydeligere føringer og veiledning til hele forvaltningen når det gjaldt håndteringen av internasjonale barnevernsaker. I tillegg endret UD noe på den interne organiseringen av arbeidet med barnevernsaker.

Gjennomføringen av Haagkonvensjonen av 1996 i norsk rett ved lov av 4. september 2015 (i kraft 1. juli 2016) er sentral for håndtering av barnevernssaker som involverer barn med tilknytning til flere stater. Haagkonvensjonen har vært i kraft siden 2002, men Norge ratifiserte den 14 år senere. De fleste EU-stater er tilsluttet konvensjonen, i tillegg til blant annet Sveits og Russland (Prop. 102 LS (2014-2015), s. 15). I ratifiseringen utarbeidet BFD et rundskriv om behandlingen av barnevernsaker der barn har tilknytning til andre land, som blant annet klargjør muligheter til samarbeid med utenlandske myndigheter (Rundskriv Q-42/2015). 
Haagkonvensjonen åpner for at en sak kan overføres til en annen konvensjonsstat når dette anses å være til barnets beste. ${ }^{22}$ Konvensjonen legger også til rette for samarbeid og informasjonsutveksling mellom konvensjonsstatene, for eksempel ved at norske barneverntjenester (via sentralmyndigheten, se nedenfor) kan innhente informasjon fra andre land om barn og barns slektninger, og motsatt kan utenlandske myndigheter innhente rapport om barn som oppholder seg i Norge.

I barnevernsaker er det primært myndigheter som treffer beskyttelsestiltak for barn, som skal anvende konvensjonen (domstolen, barneverntjenesten, fylkesnemnda, fylkesmannen og andre som tar avgjørelser). Konvensjonen har imidlertid også betydning for foreldrenes rettigheter og muligheter for å forebygge og løse foreldretvister og barnevernsaker. I barnevernsaker kan foreldre for eksempel be nasjonale myndigheter om å vurdere overføring av jurisdiksjon eller plasseringer i fosterhjem eller institusjon i en annen konvensjonsstat (lov nr. 85 av 4.9.2015; forskrift 2016-0607-604; Regjeringens informasjonssider, 2017). I lys av utfordringene vi har dokumentert i denne artikkelen, er ratifiseringen av Haagkonvensjonen viktig fordi den åpner for mer samarbeid på tvers av landegrenser i barnevernsaker. Dermed burde behovet reduseres for å løfte sakene opp på et diplomatisk nivå for å forsøkes løst.

Fra domstolenes anvendelse av konvensjonen kan en rettskraftig lagmannsrettsdom fra våren 2017 nevnes (LG-2016-77556). I den kom retten til at vilkårene for omsorgsovertagelse var til stede for fire søsken født i Norge av utenlandske foreldre. Likevel vurderte retten om hensynet til barnas beste tilsa at barna, som var russiske statsborgere, burde plasseres frivillig i fosterhjem hos mormor i utlandet. En av endringene i barnevernloven som Haagkonvensjonen førte til, var nettopp muligheten for frivillig plassering i fosterhjem eller institusjon i andre land som er tilsluttet konvensjonen, slik blant annet Russland er (se barnevernloven $\ 4-4 \mathrm{a}$; lov nr. 85 av 4.9.2015 \$ 2; forskrift nr. 604 av 7.6.2016 \1).

I forbindelse med ratifiseringen av Haagkonvensjonen opprettet BFD en norsk sentralmyndighet for saker etter konvensjonen, slik alle medlemslandene forplikter seg til å gjøre. Sentralmyndigheten er lagt til Bufdir ved avdelingen Internasjonal sentralmyndighet for barnevernsområdet. Sentralmyndigheten har fire årsverk og har i hovedoppgave å håndtere saker etter Haagkonvensjonen, samt å bygge opp sin kompetanse på internasjonale barnevernsaker, som øker i omfang etter hvert som stadig flere barn og foreldre har tilknytning til flere stater. ${ }^{23} \mathrm{Da}$ vi intervjuet representanter for sentralmyndigheten i Bufdir, hadde Haagkonvensjonen vært i kraft i cirka ti måneder, men sentralmyndigheten hadde fått over 100 saker til

\footnotetext{
${ }^{22}$ «En slik anmodning om overføring av jurisdiksjon forutsetter at barneverntjenesten anser denne staten for å være bedre egnet til å vurdere barnets beste i den konkrete saken, og at barnet kan bli bedre ivaretatt i den andre konvensjonsstaten. En overføring av jurisdiksjon innebærer at den nye staten vil få ansvaret for å treffe nødvendige beskyttelsestiltak for barnet.» (Prop. 102 LS (2014-2015), s. 56).

${ }^{23}$ Se f.eks. tildelingsbrev -2015 - tillegg nr. 3 s. 2, fra BFD til Bufdir.
} 
behandling - langt flere enn antatt på forhånd, og langt flere enn for eksempel sentralmyndigheten i Danmark. ${ }^{24}$

Utarbeidelse av et rundskriv var også et viktig langsiktig tiltak fra norske myndigheters side. En av hensiktene bak rundskrivet var å veilede kommunene i hvordan barnevernsaker over landegrensene skal håndteres (Utenriksdepartementet, 2017a). Videre har rundskrivet klargjort, for både fylkesnemndene og tingrettene, partenes rett til konsulær bistand slik den følger av Wien-konvensjonen om konsulært samkvem av 1963, og av barnevernlovens regler om hvem som kan være til stede under forhandlingsmøter i nemnda (bvl. $\$ 7-16$ ). Reglene innebærer at representanter fra utenlandske myndigheter (i praksis fra ambassader), kan få tillatelse til å overvære forhandlingsmøtet i fylkesnemnda. De tilstedeværende har taushetsplikt og referatforbud om det som kommer frem i møtet, med mindre fylkesnemnda bestemmer noe annet. Slik konsulær tilstedeværelse mener to nemndsledere at bidro til at utenlandske myndigheter ble informert om og forsto alvoret i barnevernsakene de overvar (Rundskriv Q-42/2015 kapittel 12; intervju med representanter for Sentralenheten for fylkesnemndene for barnevern og sosiale saker, 28. mars 2017). ${ }^{25}$

Til sist, utviklingen i UD gikk fra en mer ad hoc håndtering av kontroversielle barnevernsaker til en mer organisert og langsiktig håndtering. Særlig Tsjekkia-saken (som i tid kom mellom Russland- og Romania-saken) synes å ha igangsatt denne utviklingen. UD har utarbeidet omfattende og lett tilgjengelig informasjonsmateriell til alle ansatte i UD. En strategisk kommunikasjonsplan ble også formulert. I planen inngår blant annet tydelige målsettinger om at norske ambassader skal være samordnet i kommunikasjon vedrørende barnevernet, og en rekke spesifikke tiltak som skal iverksettes, er stipulert. Samarbeidet med BFD og Bufdir med hensyn til kommunikasjon er også blitt tettere og mer dynamisk i løpet av de siste årene (intervju med representanter for Utenriksdepartementet, 28. mars 2017).

Et særlig viktig felles tiltak fra UD, BFD og Bufdir var organiseringen av et informasjonsmøte for alle ambassadene i Oslo. Møtet markerte ratifiseringen av Haagkonvensjonen, og deltakerne ble gitt informasjon om norsk barnevern og barnevernloven. 65 representanter fra 51 ambassader, mange av dem ambassadører, deltok. Blant innlederne var leder for Sentralenheten for fylkesnemndene for barnevern og sosiale saker, Pernille Smith, samt daværende statsråd Solveig Horne

\footnotetext{
${ }^{24}$ Noen saker gjelder henvendelser om informasjon (sosial rapport) om barn som bor i Norge, men som har tilknytning til utlandet. Flere gjelder videreformidling av bekymringsmeldinger (både til og fra Norge). Noen har vært hastesaker om barn som er etterlatt i Norge (foreldre som har sendt barna alene til Norge for at de skal få norske fosterhjem), og noen saker har dreiet seg om foreldre og barn som forlater Norge før sak er fremmet for fylkesnemnda. Konvensjonen giør det mulig for norske barnevernmyndigheter å hjelpe barn som oppholder seg i utlandet, men som har vanlig bosted i Norge. I noen saker er jurisdiksjon overført mellom land. Så langt har erfaringene med landene sentralmyndigheten har samarbeidet med, vært hovedsakelig positive. De aktuelle landene er Sverige, Spania og Litauen (intervju med representanter fra Bufdir, 12. mai 2017).

${ }^{25}$ Representanter fra sentralmyndigheten for fylkesnemndene for barnevern og sosiale saker hadde på forhånd fått en del av våre spørsmål besvart av to fylkesnemndsledere.
} 
(intervju med representanter for Sentralenheten for fylkesnemndene for barnevern og sosiale saker, 28. mars 2017; Utenriksdepartementet, 2017a).

UD, BFD og Bufdir ble også enda mer aktivt til stede på sosiale medier. Dette synes særlig å ha kommet under og i etterkant av Tsjekkia-saken. Sosiale medier har fortsatt å være en viktig kanal for UD og var også sentrale i UDs håndtering av Romania-saken. I tett samarbeid med UD opprettet BLD blant annet en egen nettside med informasjon om norsk barnevern på regjeringen.no, og linker herfra kunne inngå i publisering av saker i sosiale medier. Kommunikasjonsenhetene i UD, BFD og Bufdir opprettet i tillegg ulike Facebook-sider, inkludert siden "Facts about the Norwegian Child Welfare Services», hvor det ble lagt ut poster på blant annet rumensk, tsjekkisk og engelsk. Nettsiden var ment som «lynavleder» for ambassade-nettsidene, slik at disse ikke skulle belastes for mye av barnevernsakene fremfor andre aktuelle bilaterale spørsmål, og slik at utenriksstasjonenes personell ikke brukte for mye tid på dette (Utenriksdepartementet, 2017a). På et tidspunkt ga tre-fem Facebook-kontoer flere hundre relativt like kommentarer på Facebooksiden "Facts about the Norwegian Child Welfare Services». Her ble det lenket til bilder av det norske flagget med hakekors og videoer av mishandlede barn. Disse Facebook-kontoene hadde svært lite innhold ut over barnevernsaken og må dermed anses som «kampanjekontoer». Kommunikasjonsenhetene slettet disse postene (Utenriksdepartementet, 2017a; intervju med representanter for Utenriksdepartementet, 28. mars 2017).

\section{Sammenligning av og sentrale trekk ved de tre sakene}

Vi åpnet denne artikkelen med spørsmålet om hvorfor de tre sakene trigget så sterke reaksjoner. Nedenfor blinker vi ut tre politiske og to rettslige faktorer som kan bidra til å forklare vanskene som oppsto.

Den politiske konteksten var sentral i alle sakene. Russland-saken kunne omdannes til et narrativ rundt en kald og ufølsom vestlig stat som angivelig opptrådte uten rettslig grunnlag, og som brøt med grunnleggende russiske familieverdier. Dette var et narrativ som passet svært bra inn i den diskursen rundt vesten som russiske medier og russiske politiske institusjoner hadde bygget opp under Vladimir Putin, og der målet syntes å være en sterk diskreditering av vestlige lands politikk og institusjoner. Antivestlig retorikk var særlig trappet opp i forbindelse med Ukraina-krisen og vestlige sanksjoner som følge av denne. I Romania var det et poeng for politiske aktører å markere handling og omtanke for rumenske borgere bosatt $i$ andre europeiske land, særlig i forkant av viktige lokale og nasjonale valg. I tillegg ble omsorgsovertagelse av barna i den norsk-rumenske familien tolket av familiens støttespillere som et brudd på retten til fri religionsutøvelse. Saken ble dermed del av et større engasjement hos mange kristne grupperinger over hele verden, for å verne om kristne verdier og sikre religionsfrihet. I India kom barnevernsaken samtidig med et viktig valg. Et av partiene som valgte å engasjere seg i saken, BJP, har en tydelig uttrykt skepsis til for mye 
vestliggjøring og fremhever viktigheten av hinduistisk kultur og verdier. Engasjementet for de indiske foreldrene kan derfor tenkes å ha sammenfalt godt med BJPs politiske agenda, selv om det bør legges til at også en rekke andre politiske grupper med ulike ståsteder engasjerte seg i denne saken.

I Romania- og Russland-sakene, men tilsynelatende ikke i India-saken, så vi at enkelte ressurssterke aktører engasjerte seg kraftig. I Russland var engasjementet til presidentens kommissær for barns rettigheter, sentralt. Dette er i seg selv ikke overraskende eller problematisk, gitt at saken hørte til kommissærens formelle portefølje. Men kommissærens valg av mediestrategi er likevel bemerkelsesverdig. Det var kommissærens pådriverrolle, inkludert hans sterkt formulerte twitter meldinger, som fikk saken på dagsordenen i nasjonale russiske medier. I Romania-saken var juristen Peter Costea en sentral pådriver. Costea hadde ingen formell rolle eller tilknytning til saken, men investerte likevel betydelig tid og penger, samt engasjerte sitt personlige nettverk i saken. Vi har ingen bevis for at aktørene som engasjerte seg i disse sakene først og fremst gjorde det av opportunistiske hensyn, men det er heller ikke det sentrale her. Uavhengig av motiv er det en viktig faktor i to av de tre sakene at sterke skikkelser med betydelige ressurser ble involvert, og at disse aktivt $ø k$ te styrken av protester mot barnevernets avgjørelser i et forsøk på å hjelpe den aktuelle familien.

I alle tre sakene ser vi altså en kombinasjon av sterke menneskelige historier $\mathrm{i}$ møte med en større agenda eller aktører i en spesifikk nasjonal kontekst. Dette er viktige faktorer i en forklaring på hvorfor sakene ble så kraftfulle og politisk betente. I tillegg ga lokale myndigheter lite eller ingen drahjelp da norske myndigheter forsøkte å håndtere protester og mediestorm. Det gjorde sakene enda vanskeligere å løse for Norge. Alle byråkratiske og politiske representanter norske myndigheter var i kontakt med i sakenes vanskeligste perioder, konkluderte med at uttalelser i favør av Norge og norske prosedyrer ville innebære uforholdsmessig stort tap av politisk prestisje eller kapital for dem i en nasjonal kontekst. Nasjonale myndigheter var dermed $\mathrm{i}$ beste fall tause eller i verste fall aktivt kritiske mot Norge i det nasjonale ordskiftet. Det kan ha svekket troverdigheten av budskapet Norge forsøkte å kommunisere, og norske representanter ble stående alene i mediestormen.

I tillegg til disse politiske faktorene ser vi særlig en tydelig rettslig faktor som gjorde seg gjeldene: taushetsplikten. De ansatte i barnevernet er som nevnt underlagt taushetsplikt og kan i utgangspunktet ikke uttale seg om konkrete barnevernsaker. Har foreldrene gått ut med informasjon til media eller samtykket til at barneverntjenesten uttaler seg, kan barneverntjenesten gi noen opplysninger, påpeke at foreldrenes fremstilling inneholder feil og lignende, men må altså også ta barnets beste $i$ betraktning, noe som ofte kan innebære at barneverntjenesten ikke bidrar til medieomtale av enkeltsaker. Begrunnelsen for den strenge taushetsplikten er særlig hensynet til at foreldre og barn skal kunne motta tjenester uten frykt for at deres kontakt med barneverntjenesten skal bli kjent for utenforstående. I et større og mer langsiktig bilde kan det være grunn til å tro at en mer utførlig informasjon til pressen 
om barnevernsaker ville svekke tilliten til barnevernet, og antagelig ville det heller ikke være til det beste for barn involvert i saker som ble omtalt i media.

Det er likevel ikke til å komme forbi at taushetsplikten ser ut til å ha svekket norske myndigheters mulighet til å oppklare misforstålser i de tre enkeltsakene vi har undersøkt i denne artikkelen. Selv om ambassadene gjentatte ganger ga generell informasjon om hvordan barnevernsaker behandles i Norge, hadde de ikke anledning til (eller ønske om) å prosedere saken i media, slik private parter kunne giøre uten særlig grunn til frykt for å bli motsagt. Barneverntjenesten og norske myndigheter hadde altså likevel mulighet til å påpeke at private parters fremstilling inneholdt feil eller var ufullstendig. Graden av taushet eller forsiktighet fra norsk forvaltnings side kan ha bli tolket som at disse aktørene ikke hadde noe å tilføye medias omtale av sakene.

I tillegg til taushetsplikten kan det også noteres en siste, rettslig faktor. Det kan diskuteres om måten den norske rettslige prosessen er lagt opp på, i noen tilfeller kan virke konfliktskapende heller en dempende. Vi skisserte denne prosessen i detalj innledningsvis. Rettssikkerhet for de involverte parter er et viktig formål med dagens prosess. Likevel kan oppbygningen rundt formelle og endelige beslutningspunkt samt utblinking av tydelige motparter som har hver sine formelle juridiske «våpendragere", ha den utilsiktede konsekvens at den skaper utrygghet og dramatikk hos berørte parter, særlig parter som er lite kjent med norsk forvaltning. I andre land vil mange plasseringer utenfor hjemmet skje i mer uformelle former.Vi skal ikke lenger enn til Sverige, hvor omsorgsovertagelse også vedtas i domstoler, men hvor partene under den muntlige delen av prosessen er plassert rundt samme bord, eller til Frankrike, hvor en barnedommer møter foreldrene (og barn som kan uttale seg) på sitt kontor og skal forsøke å oppnå familiens støtte til tiltaket (Bragdø, 2002, s. 303-304; lag (1990: 52) med särskilda bestämmelser om vård av unga; Code civil art. 375 flg.). Den rettslige iscenesettelsen i norske barnevernsaker kan dessuten tenkes å gi kilde til godt mediestoff.

Den norske barnevernprosessen er resultatet av nasjonal utvikling i retning av mer rettssikkerhet i form av det sikreste vi kjenner: en domstollignende avgjørelsesprosess. Mens saker befinner seg i den kommunale barneverntjenesten, kan dialogen mellom ansatte i barnevernet, private parter og eventuelle andre som er inne i saken (sakkyndige osv.), langt på vei skje på den måten de involverte ønsker eller evner. I noen saker er det hyppigere kommunikasjon og mer samarbeid enn i andre. Men når så inngripende tiltak som plassering av barn i fosterhjem med mer skal besluttes, overføres saken til de statlige og uavhengige fylkesnemndene, hvor formen på dialogen endres til den vi finner i rettssaker: Kommunikasjon skjer først og fremst i prosesskriv mellom partenes advokater og fylkesnemmda, i tillegg til et muntlig forhandlingsmøte etter mønster fra en hovedforhandling i tingretten. Selv om denne formen kan tenkes å virke konfliktskapende i noen tilfeller, er den et ønsket resultat av flere reformer og evalueringer hvor målet har vært å styrke foreldres og barns rettssikkerhet. Barnevernloven ( $(7-25)$ åpner for forsøk med en mindre formell samtaleprosess, men et sentralt motargument er at barneverntjenesten på den ene 
siden og private parter på den andre siden ikke er likeverdige parter (Ot.prp. nr. 76 (2005-2006) pkt. 5.13.4). ${ }^{26}$

Samlet sett finner vi altså at prosess- og taushetspliktsreglene slik de ble (korrekt) praktisert, i kombinasjon med de politiske kreftene vi har beskrevet over, gir en forklaring på hvorfor de tre sakene ble så betente.

Materialet vi har samlet inn, rommer dessuten en annen viktig tilleggsobservasjon. Idet vi startet dette prosjektet, var vi særlig opptatt av å undersøke om utenlandske myndigheter hadde forsøkt å påvirke utfallet i saker, og om fylkesnemndenes uavhengighet var blitt truet. Våre tilgjengelige data avkrefter denne mistanken. Representanter fra Sentralenheten for fylkesnemndene for barnevern og sosiale saker mente at enkelte internasjonale barnevernsaker hadde medført stort "trykk», men at fylkesnemndslederne hadde merket lite til dette, og de var ikke kjent med tilfeller hvor utenlandske myndigheter hadde forsøkt å påvirke utfallet av saker $\mathrm{i}$ fylkesnemndene. ${ }^{27}$

\section{Avslutning}

Over har vi beskrevet det diplomatiske hodebryet tre barnevernsaker ga Norge i årene 2012 til 2017. Vi har også skissert fem faktorer som kan bidra til å forklare hvorfor de tre barnevernsakene ble så diplomatisk og politisk betente. I avslutningen på denne artikkelen setter vi frem et par betraktninger om hvordan norske myndigheter generelt og utenrikstjenesten spesielt takler den type saker som barnevernskontroversene representerer.

Jonas Gahr Støre (2008) beskrev i sin bok fra tiden som utenriksminister, en av de første indiske sakene som skapte betydelige reaksjoner. Idet saken eskalerte, noterte han at krisen ikke var på den offisielle dagsordenen i UD, og lederne i departementet stilte seg undrende til oppstyret saken hadde skapt. Det hersket også usikkerhet om hvordan saken skulle gripes an (Støre, 2008).

Spørsmålet vi stiller oss etter arbeidet med denne artikkelen, er om den byråkratiske og politiske toppledelsen i UD og fortsatte å ignorere denne type saker i årene etter 2008. Ble det tatt overordnede og strategiske grep på et tidspunkt som kan anses å være tilstrekkelig tidlig - altså på et tidspunkt man kan forvente at de burde ha blitt tatt? Ut fra det begrensede materialet vi har hatt tilgang til i arbeidet med denne

\footnotetext{
${ }^{26}$ Det er også foreslått at partene ikke plasseres på hver sin side av en sal, men rundt samme bord, se Bragdø (2002). Mer om utviklingen av saksbehandlingen ved inngripende beslutninger i barnevernet, se for eksempel Olsen (2002).

${ }^{27}$ To fylkesnemndsledere hadde via Sentralenheten for fylkesnemndene for barnevern og sosiale saker besvart spørsmål fra oss, og heller ikke disse hadde opplevd forsøk på påvirkning. De to nemndslederne hadde ikke opplevd at utenlandske myndigheter hadde gjort forsøk på utidig innblanding, men hadde ved en anledning måtte hindre to utenlandske representanter som hadde vært til stede under forhandlingsmøte (konsulær bistand), i å hjelpe en privat part med å forklare seg og i å ta bilder. Nemndslederne var også kjent med at tsjekkiske myndigheter ville hjelpeinterveniere i en sak mot Norge for EMD.
} 
korte artikkelen, kan det synes som at utfordringene mest av alt har blitt besvart på departementalt mellomledernivå, og at det på dette nivået, som reaksjon på den faktiske utviklingen, har skjedd kloke rokeringer som kan sikre at Norge er bedre rustet til aktiv og tidlig håndtering av fremtidige barnevernsaker med internasjonalt tilsnitt. Dersom vår oppfatning er korrekt, er dette et eksempel på at byråkratiene i UD og BFD viser god evne til læring og utvikling. De er «lærende organisasjoner» $\mathrm{i}$ henhold til Peter Senges formulering (Senge, 2014).

Samtidig ser vi også et mulig negativt trekk i Norges respons på disse internasjonale kontroversene: Den sene ratifiseringen av Haagkonvensjonen kan ha vært en hemsko for norske myndigheter idet de forsøkte å håndtere de tre sakene vi har valgt ut her. Dersom ratifiseringen hadde vært på plass tidligere, ville de aktuelle etatene ha hatt flere gode verktøy tilgjengelig, som igjen kanskje kunne ha bidratt til at det ble mindre støy rundt disse eller lignende saker. Sammenlignbare land som Danmark og Sverige hadde ratifisert Haagkonvensjonen flere år før Norge. I samtalene med våre intervjuobjekter var det få som kunne si noe om årsaken til at Norge var sen. Et intervjuobjekt påpekte at norske barnevernmyndigheter ikke har vært udelt positive til Haagkonvensjonen fordi konvensjonen potensielt overfører ansvar til barnevernsystemer der kvalitet og terskel for omsorgsovertagelse er en annen enn i Norge. Norske myndigheter har derfor vært bekymret for at dette kan slå uheldig ut for noen barn (intervju med representant for Bufetat, 11. desember 2018). En annen mulig forklaring kan være at eierskapet til denne saken var delt mellom to departementer. BFD var det ansvarlige fagdepartementet for ratifiseringen av Haagkonvensjonen og selve sakene, mens de sterke reaksjonene mot Norge i de enkelte landene har blitt håndtert av UD. Dette kan ha pulverisert ansvaret. En tredje mulighet er at BFD ikke i tilstrekkelig grad prioriterte internasjonale spørsmål i denne perioden.

Uansett forklaring reiser dette et spørsmål om hvorvidt UD og BFD burde ha diskutert og klargjort på et tidligere tidspunkt om ratifiseringen av Haagkonvensjonen var hensiktsmessig eller ikke, og at det i den forbindelse burde ha kommet et mer tydelig påtrykk og engasjement fra byråkratisk og politisk toppledelse. I strategifaget forventer man at en toppledelse blant annet skal evne å se fremover og formulere en retning som gjør organisasjonen i stand til å takle nåværende og fremtidige utfordringer som organisasjonens spesifikke kontekst gir (Mintzberg et al., 2009, s. 16 og 132). Barnevernsaker har tradisjonelt vært saker som ikke har hatt stor diplomatisk betydning for Norge, og det er dermed forståelig at toppledelsen i UD og BFD tilsynelatende ikke engasjerte seg på et tidlig tidspunkt.

I faget internasjonal politikk deler vi gjerne saker inn i kategoriene «high politics", som er knyttet til eksistensielle trusler, militærmakt og stormaktspolitikk, og «low politics», som er knyttet til myriader av mer eller mindre enkeltstående saker. ${ }^{28}$

\footnotetext{
${ }^{28}$ «Gjensidig avhengighet» betyr at en part er avhengig av motparten for at et foretrukket resultat skal kunne oppnås (Keohane \& Nye, 2001; Neumann et al., 2008). For en videre diskusjon av begrepene high politics og low politics, se Nye (1965).
} 
Sistnevnte er ofte er av økonomisk eller sosial art, og gjensidig avhengighet mellom de involverte landene er et fremtredende trekk. I slike saker er samhandling mellom spesialister og embetsmenn på lavere nivå ofte like viktig som forhandlinger på statsledernivå. Håndtering av barnevernsaker som har et internasjonalt tilsnitt, er et typisk eksempel på «low politics».

Ut fra en tradisjonell forståelse av internasjonal politikk vil vi forvente at toppledelsen i UD nedprioriterer disse sakene og vier «high politics» størst oppmerksomhet. Samtidig er et sentralt trekk ved internasjonal politikk i vårt tiår nettopp sammenblandingen av «low politics» og «high politics». Migrasjonskrisen i Europa de siste fem årene er et eksempel på et tradisjonelt «low politics»-tema som har fått storpolitisk betydning. Globaliseringen har bidratt til en tettere sammenveving av samfunn og aktiviteter over hele verden, slik at endringer ett sted kan gi store og uforutsette konsekvenser andre steder - raskere og i mye større grad enn tidligere (Giddens, 1999; Ramo, 2009; Naim, 2014). Mindre og tilsynelatende ubetydelige saker kan gis ny dynamikk og mening og kan utvikle seg til å få stor nasjonal betydning (Ramo, 2009). God strategisk ledelse på utenriksfeltet i vårt tiår må dermed innebære blant annet evnen til å forstå spillet mellom «high politics» og «low politics», til å identifisere «low politics»-saker som kan få nasjonal relevans på et tidlig tidspunkt, og til å ta grep som kan bidra til best mulig håndtering. Dersom vi bruker barnevernsakene og mangel på klargjøring rundt Haagkonvensjonen som utgangspunkt, er vår tolkning at toppledelsen i UD ikke i tilstrekkelig grad demonstrerte denne evnen i den aktuelle perioden. ${ }^{29} \mathrm{BFD}$ er ansvarlig fagdepartement for sakene, men evnen og ressursene til å lese den internasjonale utviklingen ligger hos UD.

Vi noterer oss også at dynamikken og samarbeidet mellom UD, BFD og Bufdir har vært avgjørende i sakene vi har sett på i denne artikkelen. Det sammenfaller godt med internasjonale studier på god organisering av byråkratier som utøver utenrikspolitikk i vår tid. Anne-Marie Slaughter er blant dem som fremhever viktigheten av at utenriksdepartementer har "convening power», altså evne til å spille andre gode eller bringe ulike aktører (offentlige, private og/eller sivilsamfunn) sammen slik at disse i felleskap effektivt kan ta opp utfordringer som har en transnasjonal karakter. ${ }^{30}$ Igjen gjetter vi at dialogen mellom UD og BFD på toppledernivå kanskje kunne ha vært bedre: Evnet toppledelsen i UD å spille toppledelsen i BFD gode når det gjaldt

\footnotetext{
${ }^{29} \mathrm{Vi}$ kan også legge til at det ikke nødvendigvis var storpolitikk og tradisjonelle «high politics»-saker som tok oppmerksomheten vekk fra "low politics»-barnevernsakene som var under oppseiling fra og med 2008. Dersom vi ville studert tidsbruk, agendaer og ressursbruk i detalj, ville vi antakelig funnet at bistand, symbol og statusrelaterte saker også tok svært mye av toppledelsens tid i UD i den aktuelle perioden (Carvalho \& Neumann, 2015; Gabrielli \& Torjesen, 2017).

${ }^{30}$ En LEAD-rapport på utfordringer for utøvelsen av tysk utenrikspolitikk hevder at utenriksdepartementer må bygge og bruke "convening power» ved å «bring the most effective, efficient, problem-oriented actors together to tackle complex challenges. [Only then] can a foreign ministry remain relevant and demonstrate its value to domestic taxpayers and to members of the international community» (LEAD, 2015, s. 9; Slaughter, 2009).
} 
internasjonale spørsmål? Dersom toppledelsen i BFD var sene i redegiørelsen av om Norge burde ratifisere Haagkonvensjonen, burde UDs toppledelse ha oppmuntret sterkere og tidligere til større fokus på denne internasjonale saken? På lavere nivå synes imidlertid et positivt element av UDs «convening power» klart å ha vært til stede.

Vi har i denne artikkelen brukt spørsmålet om hvorfor sakene trigger så sterke reaksjoner, som utgangspunkt for vår analyse. Like interessant kunne det kanskje være å spørre hvorfor det er særlig fra perioden rundt 2008 og senere at det kommer en økning i antall barnevernsaker som gir diplomatiske utfordringer? Én forklaring kan være at antallet familier i Norge med utenlandske foreldre rundt 2008-2010 ble så høyt at kontroverser ble mer sannsynlig. ${ }^{31}$

En annen mulighet er å lete etter en forklaring på mer storpolitisk eller strukturelt nivå. Kontroverser rundt norske regler om omsorg for barn og håndhevelsen av disse reglene meldte seg på et tidspunkt da vestlige lands definisjonsmakt opplevde en særlig svekkelse, altså at vestlige prinsipper og fortolkninger i mindre grad fikk særlig forrang eller relativt sett sterkere troverdighet. Samtidig fikk mange nye fremvoksende stater sterkere behov for å markere en selvstendig utenrikspolitisk linje og demonstrere for egne borgere en evne til å agere effektivt og uavhengig i internasjonal politikk. ${ }^{32}$ Det kan tenkes at 2008 er nettopp det tidspunktet da verden merkbart beveget seg $\mathrm{i}$ en multipolar retning, og at dette ga en mer opportun kontekst for internasjonale kontroverser rundt barnevern. I så fall er det på sin plass å påpeke at bevegelsene mot en mer fragmentert verden og svekket vestlig definisjonsmakt, sannsynligvis vil fortsette i perioden fremover og vil vedvare å gi slike opportune rammer.

I denne artikkelen har vi sett at Norge nå er mye bedre rustet til å takle internasjonale barnevernsaker. Det er betryggende. Likevel, vi tror andre, lignende verdirelaterte saker der våre liberale tolkninger, institusjoner og prosedyrer stilles spørsmål ved, lett kan oppstå i tiden fremover. Etter arbeidet med denne artikkelen finner vi

\footnotetext{
${ }^{31}$ Av befolkningen mellom 0 og 22 år utgjør 13,6 prosent innvandrere eller norskfødte barn med innvandrerforeldre. Denne gruppen barn vokste med hele 25 prosent bare fra 2010 til 2013 (Dyrhaug \& Sky, 2012, s. 4; Lineikro, 2017, s. 5). I takt med at innvandrerbefolkningen steg, økte også antall barnevernsaker med fremmedkulturelle parter. Andelen fosterbarn med fremmedkulturell bakgrunn økte fra 16 prosent i 1995 til 25 prosent i 2010 (Lineikro, 2017, s. 5; BackeHansen, Havik \& Backer Grønningsæter (red.), 2013, s. 49).

${ }^{32}$ Se f.eks. Zakaria (2011). Andrew Hurrell (2013) understreker at mens makten før var konsentrert hos noen få aktører, er det nå mange flere stater som har betydelig innflytelse - vi ser både flytting og oppsplitting av makt. For Hurrell ligger makt alltid bakenfor verdier i internasjonal politikk, og når makten endrer seg, endrer også spillerommet for liberale verdier seg. Et hovedpoeng for Hurrell er at vi ikke lenger kan være sikre på at det vil være objektiv enighet og forståelse for initiativ som vi ser på som idealistiske, gjennom for eksempel en forankring i internasjonal rett. Det vil være politisk kamp rundt forståelse av alle initiativ, også dem som er ment å oppnå idealistiske mål.Vi er tilbake til en verden som resonnerer med E.H. Carrs observasjoner av utenrikspolitikk i mellomkrigstiden, altså at «no value is absolute» (Carr, 1939, s. 13), og at alle saker har en iboende politisk kamp i seg (Gabrielli \& Torjesen, 2017).
} 
det fortsatt betimelig å stille spørsmål ved om Norge gjennomgående har rigget det utenrikspolitiske maskineriet godt nok til å håndtere denne type utfordringer, som ventelig kan komme.

\section{Om forfatterne}

Sunniva C. Bragdø-Ellenes er førsteamanuensis ved Universitetet i Agder, hvor hun har undervisningsansvar for forvaltningsrett. Hun forsker på blant annet forvaltningsrett, komparativ forvaltningsrett, prosessrett, domstoler og domstollignende forvaltningsorganer og barnevernrett. Hun har blant annet jobbet som fylkesnemndsleder ved Fylkesnemnda for barnevern og sosiale saker i Agder.

Stina Torjesen er førsteamanuensis ved Universitetet i Agder, hvor hun underviser i internasjonal politikk og internasjonal politisk økonomi. Torjesen har en doktorgrad i Internasjonal Politikk fra Universitetet i Oxford og arbeidet tidligere i FN og ved Nupi.

\section{Takk}

Forfatterne ønsker å takke Utenriksdepartementets Seksjon for konsulære saker for god hjelp og organisering av informasjon etter forespørsel om innsyn. Forfatterne ønsker også å takke Professor Elisabeth Gording Stang for innsikt og veiledning på den bredere nasjonale debatten om barnevernet i Norge.

\section{Litteraturliste}

Backe-Hansen, E., Havik, T. \& Backer Grønningsæter, A. (Red.) (2013). Fosterhjem for barns behov. Rapport fra et fireårig forskningsprogram. NOVA Rapport 16/2013.

BBC News (2012, 23. Januar). India to take up child custody dispute with Norway.

Berg, B., Paulsen, V., Midjo, T., Haugen, G. M. D., Garvik, M., Tøssebro, J. (2017). Myter og realiteter. Innvandreres møter med barnevernet. Trondheim: NTNU.

Bufdir Statistikk og analyse. Barnevern (2017). Hentet 18.9.2017 fra https:/www.bufdir.no/Statistikk_og_ analyse/Barnevern.

Burns, K., Pösö, T. \& Skivenes, M. (Red.) (2016). Child welfare removals by the state: A cross-country analysis of decision-making systems. New York: Oxford University Press.

Bragdø, S. C. (2002). Rettssikkerhet i fylkesnemndene i et internasjonalt perspektiv. I A. Kjønstad (Red.), Barnevern, fylkesnemnder og rettssikkerhet. Oslo: Gyldendal Akademisk.

Carr, E. H. (1939). The twenty years crisis: 1919-1939.

Costea, P. et al. (2016). International petition for the release of the Bodnariu children. Brev til statsminister Solberg, 12. mai 2016.

de Carvalho, B. \& Neumann, I. B. (Red.). (2015). Small states and status seeking: Norway's quest for international standing. London and New York: Routledge.

Dyrhaug, T. \& Sky, V. (2012). Barn og unge med innvandrerbakgrunn i barnevernet 2012. SSB rapporter 2015/16.

Emberland, M. (2016). Det norske barnevernet under lupen. Lov og Rett, nr. 6, 329-330.

Emberland, M. (2018). Det norske barnevernet under lupen - del 3. Lov og Rett nr. 10, 583-584.

Gabrielli, K. N. \& Torjesen, S. (2017). Sosialdemokratisk utenrikspolitikk i Trumps verden. Oslo: Form Forlag.

Giddens, A. (1999). Runaway world: How globalisation is reshaping our lives. London: Profile Books.

Helmikstøl, Ø. (2015). Bekymringsmelding møtt med taushet. Psykologtidsskriftet, utgave 9-2015. Hentet 20.6.2017 fra http://psykologtidsskriftet.no/index.php?seks_id=450203\&a=3. 


\section{Sunniva Cristina Bragdø-Ellenes og Stina Torjesen}

Hurrell, A. (2013). Power transitions, emerging powers, and the shifting terrain of the middle ground. I C. Navari (Red.), Ethical reasoning in international affairs. UK: Palgrave Macmillan.

itroms.no (2014, 27. oktober). Russiske myndigheter griper inn barnevernsak $i$ Tromsø.

Kalve, T. \& Dyrhaug, T. (2009). Barn og unge med innvandrerbakgrunn i barnevernet 2009. SSB Rapporter 39/2011.

Keohane, R. O., \& Nye, J. S. (2001). Power and interdependence. 3. utg. New York: Longman.

LEAD (2015). Networked foreign policy for the 21st century how leaders can drive change in the digital age. LEAD Research Series, Berlin: LEAD/Mercator Capacity Building Center for Leadership \& Advocacy.

Lineikro, H. C. (2017). Betydningen av barnets kulturelle bakgrunn ved fosterhjemsplassering etter omsorgsovertakelse. Masteroppgave. Universitetet i Bergen.

Mintzberg, H., Ahlstrand, B. \& Lampel, J. (2009). Strategy safari:Your complete guide through the wilds of strategic management. Upper Saddle River: Pearson Education Limited.

Naim, M. (2014). The end of power: From boardrooms to battlefields and churches to states, why being in charge isn't what it used to be. New York: Basic Books.

Neumann, I. B., Carlsnaes, W., Skogan, J. K., Græger, N., Rieker, P., Haugevik, K. M. \& Torjesen, S. (2008). Norge og alliansene. Oslo: NUPI.

NRK (2016, 16. april). Global d-dag mot norsk barnevern.

Nye, J. S. (1965). Patterns and catalysts in regional integration. International Organization, 19(4).

Oppedal, M. (2008). Akutthjemlene i barnevernloven. Oslo: Gyldendal akademisk.

Olsen, B. K. (2002). Historisk perspektiv på rettssikkerheten i barnevernet. I A. Kjønstad (Red.), Barnevern, fylkesnemnder og rettssikkerhet. Oslo: Gyldendal akademisk.

Paulsen,V., Thorshaug, K. \& Berg, B. (2014). Møte mellom innvandrer og barnevernet. Kunnskapsstatus. Trondheim: NTNU Samfunnsforskning.

Romanian National News Agency (2016, 23. januar). Bodnariu family might get back its children after Romanian Parliament delegation visit to Norway.

Slaughter, A. M. (2009). America's Edge. Foreign Affairs, 88(1), 94-113.

Støre, J. G. (2008). Å gjøre en forskjell: refleksjoner fra en norsk utenriksminister. Oslo: Cappelen Damm.

Thune, skrevet av Gro Hillestad, Thea Totland, Nina Witoszek, Elvis Nwosu \& Einar C. Salvesen (2015) Bekymringsmelding om barnevernet. Aftenposten 10. juni 2015.

Prop. 102 LS (2014-2015). Lov om gjennomføring av konvensjon 19. oktober 1996 om jurisdiksjon, lovvalg, anerkjennelse, fullbyrdelse og samarbeid vedrørende foreldremyndighet og tiltak for beskyttelse av barn, og endringer i enkelte andre lover, og samtykke til ratifikasjon av konvensjonen (s. 15).

Ot.prp. nr. 76 (2005-2006). Om lov om endringer i barnevernloven og sosialtjenesteloven mv. (saksbehandlingsregler for fylkesnemndene for barnevern og sosiale saker mv.).

NOU 2012: 5 (2012). Bedre beskyttelse av barns utvikling.

NOU 2016: 16 (2016). Ny barnevernslov.

NOU 2017: 8 (2017). Særdomstoler på nye områder?

Uutiset $(2014,15$. november). Russian child ombudsman: Finland engaging in juvenile terror.

Utenriksdepartementet (2015a). Barnevernsaker, Russlands barneombud. Flak til spørretime SMIN 11. februar og UMIN 18. februar.

Utenriksdepartementet (2015b). Romania og Norge. Barnevern. Politiske Samtaler, e-post 26. november.

Utenriksdepartementet (2016a). Barnevern - saker som gjelder barn med tilknytning til flere land, 29. april.

Utenriksdepartementet (2016b). Romania @ demonstrasjoner mot Norge, e-post 17. april.

Utenriksdepartementet (2016c). Østerrike: Demonstrasjonene mot barnevernet 16.04, e-post 18. april.

Utenriksdepartementet (2016d). Europarådet @ barnevern - rumenske medier, e-post 3. juni.

Utenriksdepartementet (2016e). «Barnevernsaken» sett fra Houston og bortover det amerikanske bibelbeltet, e-post 18. mai.

Utenriksdepartementet (2016f). Barnevern. Demos 16 april 2016. Oppsummering fra stasjonene, e-post 20 april.

Utenriksdepartementet (2017a). E-post til forfatterne av artikkelen, 18. oktober.

Ramo, J. C. (2009). The age of the unthinkable: Why the new world disorder constantly surprises us and what we can do about it. UK: Hachette.

Regjeringens informasjonsside om Haagkonvensjonen 1996 (2017). Hentet fra https://www.regjeringen.no/no/ tema/familie-og-barn/innsiktsartikler/haagkonvensjonen- 1996/informasjon-om-haagkonvensjonen-1996/ id2506528/.

RFE/RL (2013). Probe into abuse of Russian orphans in U.S., 27. november.

Rundskriv Q-24, mars 2005 Barnevernet og taushetsplikten, opplysningsretten og opplysningsplikten punkt.

Rundskriv Q-42/2015 Retningslinjer om behandlingen av barnevernsaker der barn har tilknytning til andre land. 
Senge, P. (2014). The fifth discipline fieldbook: Strategies and tools for building a learning organization. New York: Crown Business.

Sentralenheten for fylkesnemndene for barnevern og sosiale saker, Fylkesnemndene (2015). Arrsrapport 2015 Fylkesnemndene for barnevern og sosiale saker.

Støre, J. G. (2008). A gjøre en forskjell. Refleksjoner fra en norsk utenriksminister. Oslo: Cappelen Damm.

TV2 (2012, 23. april). De indiske barna drar hjem med onkelen.

YouTube (2014, 29. oktober). Russia: Watch Norwegian embassy protest salmon-stompers protest child detention.

Zakaria, F. (2011). The post-American world, release 2.0. New York: W. W. Norton \& Company.

\section{Intervjuer}

Intervju med representanter fra Utenriksdepartementet, 3. mars 2017.

Intervju med representanter fra Utenriksdepartementet, 28. mars 2017.

Intervju med representanter fra Sentralenheten for fylkesnemndene for barnevern og sosiale saker, 28. mars 2017.

Intervju med representant fra Utenriksdepartementet, 29. mars 2017.

Intervju med representanter fra Utenriksdepartementet A, 31. mars 2017.

Intervju med representant fra Utenriksdepartementet B, 31. mars 2017.

Intervju med representanter fra Bufdir, 12. mai 2017.

Intervju med representant fra Bufetat, 11. desember 2018.

\section{Rettspraksis}

Dom fra Gulating lagmannsrett, LG-2016-77556.

Dommer fra Den europeiske menneskerettsdomstolen (EMD), klagesak nr. 43701/14; 27496/15; 64808/16; $37283 / 13 ; 60371 / 15 ; 2822 / 16 ; 39710 / 15,15379 / 16$ og 14652/16.

\section{Abstract in English \\ Diplomatic Controversies Sparked by Decisions of the Norwegian Child Welfare Service: A Preliminary Assessment}

Decisions taken by the Norwegian child welfare services have in the past decade, in some cases, created strong international reactions. In the spring of 2016, over 8,000 people in eleven countries demonstrated in connection with a case involving a Norwegian-Romanian family. This article examines three issues that have presented significant diplomatic challenges to Norway (India 2011, Russia 2014 and Romania 2016). The article looks at why the cases triggered such strong reactions and explains how the Norwegian authorities handled these cases. It also outlines the relevant Norwegian legislation and judicial procedures in the field. The paper finds that the three controversial cases assessed linked with other strong driving forces or national political issues in the country in question. In the material we present, there is also evidence of learning and improvement in the way the Norwegian Ministry of Foreign Affairs handled these challenges, and there also seems to have been improvement in the way the Ministry of Foreign Affairs collaborated with other parts of the civil service. At the same time, the article questions why a key tool in dealing with these types of cases (The 1996 Hague Convention) was ratified so late in Norway.

Keywords: India $\cdot$ Russia $\cdot$ Romania $\cdot$ Norwegian foreign policy $\cdot$ child welfare services 